\title{
VIABILIDADE DO MANEJO DE PRAGAS NA CULTURA DO ALGODOEIRO EM FÁTIMA DO SUL-MS
}

\author{
CARMO TOLEDO FERRAZ \\ Engenheiro Agrônomo
}

Orientador: Prof. Dr. OCTÁvio NAKANO

Dissertação apresentada à Escola Superior de Agricultura "Luiz de Queiroz", da Universidade de São Paulo, para obtenção do título de Mestre em Ciências Biológicas: Área de Concentração: Entomologia.

$P|R A C| C A B A$

Estado de São Paulo - Brasil

Julho - 1986 
E R R A T A

VOL. II - PERNAMBUCO

\begin{tabular}{|c|c|c|c|}
\hline Pag. & Linha & Onde se le & Leia-se \\
\hline 13 & 26 & (10YR $4 / 6)$ & $(10 \mathrm{R} \quad 4,6)$ \\
\hline 17 & 8 & p•r sedimentação & por tamização e sedimentação \\
\hline 17 & 9 & koettigen & xoettgen \\
\hline 17 & 16 & e cilindro & ent cilindro \\
\hline 148 & 5 & to levemente & zo levemente \\
\hline 180 & $8 e 9$ & c & IIC \\
\hline 181 & - & $\mathrm{Kr}$ & $\mathrm{Ki}$ \\
\hline $18 ?$ & $\ldots$ & $\frac{\mathrm{Al}_{2} \mathrm{O}_{3}}{\mathrm{Fe}_{2} \mathrm{O}_{3}}$ & $\mathrm{Kr}$ \\
\hline 181 & - & $P$ assinil. (ppm) & $\frac{\mathrm{AJ}_{2} \mathrm{O}_{3}}{\mathrm{Fe}_{2} \mathrm{O}_{3}}$ \\
\hline 292 & 9 & Fábrica Sta Rosa & Fábrica Rosa. \\
\hline 306 & 22 & cassatinga & sacatinga \\
\hline 306 & 23 & caixa-cubri & caxacubri \\
\hline
\end{tabular}


A minha esposa EMILIA, OFEREÇO.

\author{
Aos meus filhos, \\ SHIRLEY, CARMO C RAQUEL,
}

DEDICO . 


\section{AGRADECIMENTOS}

- Ao Prof. Dr. OCTÂVIO NAKANO, pela orientação na execução de $\underline{s}$ te trabalho;

- A todos os professores do Departamento de Entomologia da Escola Superior de Agricultura "Luiz de Queiroz", pela amizade e ensinamentos transmitidos;

- Ao Dr. Ervino Bleicher pelas sugestóes e colaboração;

- Ao Dr. José Roberto Salvadori, pela amizade e colaboração;

- A Escola Superior de Agricultura "Luiz de Queiroz", da Universidade de São Paulo, em Piracicaba, pela oportunidade con cedida para a realização do Curso de Pós-Graduação;

- A Empresa de Pesquisa, Assistência Técnica e Extensão Rural de Mato Grosso do Sul (EMPAER), pela oportunidade concedida para a realização do curso;

- Ao Prof. Dr. Evoneo Berti Filho, pela colaboração prestada na elaboração do "Summary";

- Aos colegas do Curso de Pós-Graduação, pela amizade; 
- A todos os funcionários do Departamento de Entomologia da Escola Superior de Agricultura "Luiz de Queiroz";

- Aos funcionários da biblioteca da ESALQ/USP;

E a todas as pessoas que direta ou indiretamente colaboraram na execução deste trabalho. 


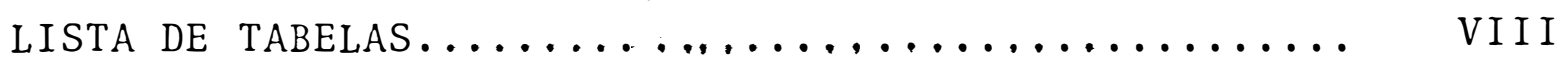

LISTA DE FIGURAS $\ldots \ldots \ldots \ldots \ldots \ldots \ldots \ldots \ldots \ldots \ldots \ldots \ldots \ldots \ldots \ldots \ldots \ldots$

LISTA DE APENDICE..................... XVII

RESUMO $\ldots \ldots \ldots \ldots \ldots \ldots \ldots \ldots \ldots \ldots \ldots \ldots \ldots \ldots \ldots \ldots \ldots \ldots \ldots \ldots \ldots$

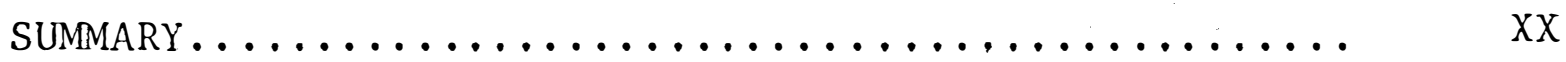

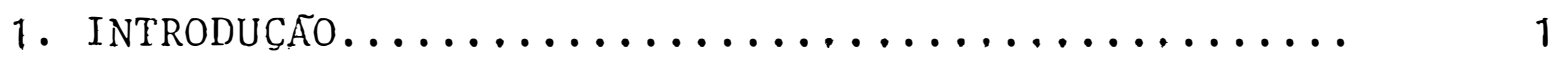

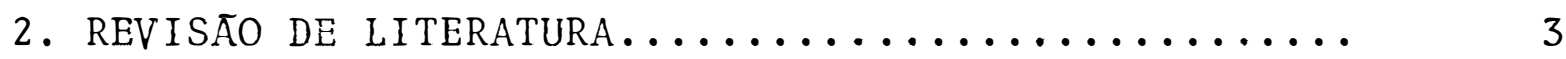

2.1. Os defensivos na lavoura algodoeira e suas con : sequências......................... 3

2.2. O manejo de pragas e seus princípios........ 7

2.3. Controle quimico e biológico............. 10

2.4. Perspectivas do manejo de pragas........... 15

2.5. Estabelecimento dos niveis de controle...... 18

2.5.1. Recomendações gerais............. 18

2.5.1.1. Uso de inseticidas no início do ciclo.............. 18

2.5.1.2. Reboleiras............. 19

2.5.1.3. Frequência de amostra para pragas e inimigos naturais..

2.5.1.4. Caminhamento........... 20

2.5.1.5. Medidas culturais........ 21 


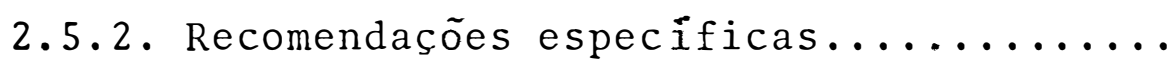

2.5.2.1. Broca do algodoeiro Eutinobo thrus brasiliensis (Hambleton, $1937) \ldots \ldots \ldots \ldots \ldots \ldots \ldots$

2.5.2.2. Tripes do algodoeiro Thrips spp., Hercothrips spp., Fran-

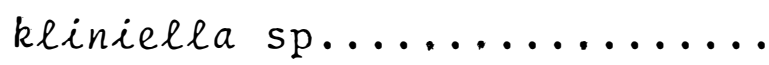

2.5.2.3. Pulgão do algodoeiro Aphis gos sypii Glover, $1877 \ldots \ldots \ldots \ldots$

2.5.2.4. Curuquerê do algodoeiro Alabama argillacea (Huebner, 1818).

2.5.2.5. Ácaro rajado Tetranychus urticae Koch, $1836 \ldots \ldots \ldots \ldots \ldots$

2.5.2.6. Ácaro branco Polyphagotarsonemus latus (Banks, 1904)......

2.5.2.7. Lagarta das maçãs Heliothis vi rescens (Fabr., 1781).......

2.5.2.8. Lagarta falsa medideira Tricho plusia ni (Huebner, 1802)....

2.5.2.9. Lagarta rosada Pectinophora gossypiella (Saund., 1844)....

2.5.2.10. Percevejo rajado Horcias nobilellus (Berg., 1883)........

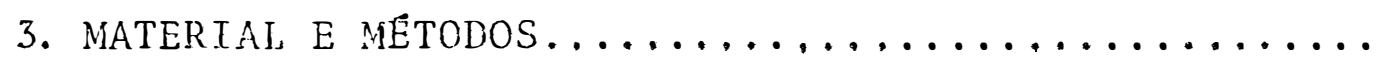


3.2. Delineamento experimental e tratamentos..... 30

3.3. Amostragens das pragas e inimigos naturais... 31

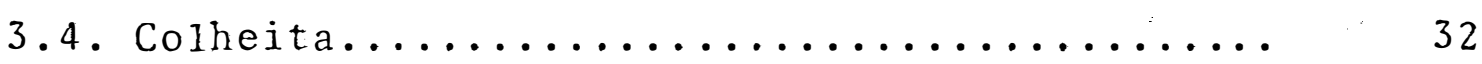

3.5. Dados meteorológicos............... 32

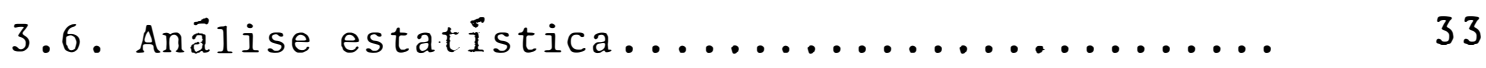

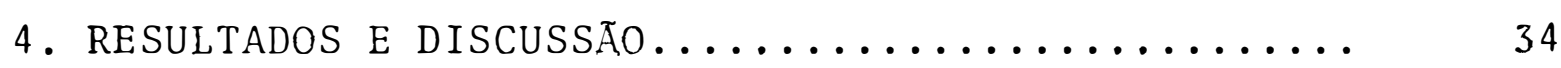

4.1. Amostragens das pragas e inimigos naturais... 34

4.2. Efeitos na produtividade.............. 35

4.3. Efeitos nos custos de tratamento........... 36

4.4. Controle do ácaro rajado Tetranychus urticae Koch, 1836 em reboleis................ 36

4.5. Efeito das sementes tratadas no controle do "complexo tripes" e pulgão Aphis gossypii Glo

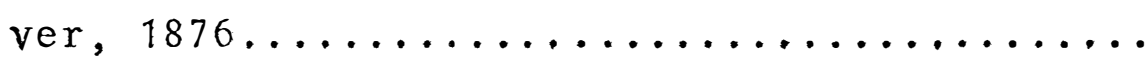

4.6. Flutuação da população de ácaro rajado Tetranychus urticae Koch, $1836 \ldots \ldots \ldots \ldots \ldots$

4.7. Efeitos do desfolhamento provocado pelo curuquerê Alabama argillacea (Huebner, 1818) na

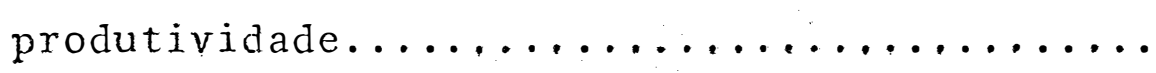

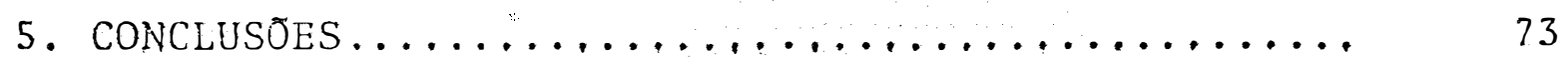

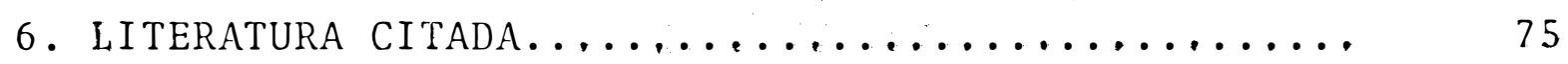

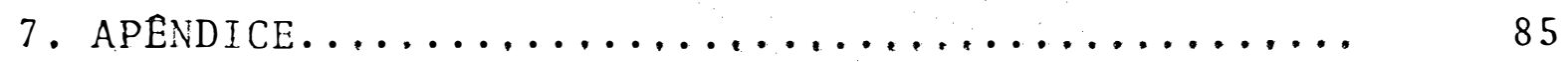


.viii.

\section{LISTA DE TABELAS}

TABELA

1 Esquema de pulverizações jreventivas e produtos mais usados em MS., 1979....... 6

2 Anālise de solo do local do experimento Fätima do Sul - MS. 1982_........... 33

3 Médias das plantas infestadas em percenta gens por pragas e inimigos naturais no tratamento manejo de pragas (M.P.).

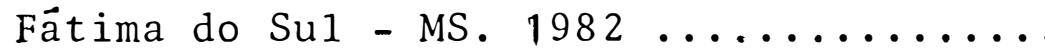

4 Médias das plantas infestadas em percenta gens por pragas e inimigos naturais no tratamento sistema do agricultor (S.A.).

Fảtima do Sul - MS. $1982 \ldots \ldots \ldots \ldots \ldots 42$

5 Médias das plantas infestadas em percenta gens por pragas e inimigos naturais no tratamento testemunha (T). Fátima do Sul MS , $1982 \ldots \ldots \ldots \ldots \ldots \ldots \ldots \ldots \ldots \ldots$ 
6 Médias das plantas infestadas em percenta gens por pragas de algodoeiro em diferentes tratamentos. Fátima do Sul - MS.1982.

7 Resumo da Anālise de Variância e do teste F para efeito äos tratamentos sobre pra gas do algodoeiro . Fátima do Sul-MS.1982

8 Médias de plantas infestadas em percentagem, por diferentes grupos de inimigos na turais das pragas do aigodoeiro, em diferentes tratamentos. Fátima do SuI-MS.1982

9 Resumo da anảlise de variância e do teste F para o efeito dos tratamentos sobre diferentes grupos de inimigos naturais das pragas do algodoeiro. Fátima do Sul - MS.

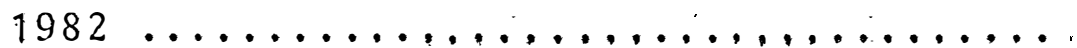

10 Produtividade média de algodão em caroço em $\mathrm{kg} / \mathrm{ha}$ da cultivar IAC-17, submetida a diferentes tratamentos. Fátima do Sul-ivs $1982 \ldots \ldots \ldots \ldots \ldots \ldots \ldots \ldots \ldots$

11 Custo total do controle de pragas (defensivo + mão-de-obra) no tratamento: manejo de pragas (M.P.). Fátima do Sul-MS.1982 
12 Custo total do controle de pragas (defensivo + mão-de-obra) no tratamento: manejo de pragas (M.P.). Fátima do Sul-MS. 1982.

13 Custo total do controle de pragas (defensivo + mão-de-obra) no tratamento: siste ma do agricultor (S.A.). Fâtima do Sul-MS $1982 \ldots \ldots \ldots \ldots \ldots \ldots \ldots \ldots \ldots \ldots \ldots$

14 Comparação entre o número de pulverizações com defensivos e seu custo total em $\operatorname{Cr} \$ /$ ha para o controle de pragas nos tratamen tǒs: sistema do agricultor (S,A.) e manejo e pragas (M.P.). Fátima do Sul. MS. $1982 \ldots \ldots \ldots \ldots \ldots \ldots \ldots \ldots \ldots \ldots \ldots$

15 Comparação entre os custos de controle de ảcaro rajado $\mathrm{cm} \mathrm{Cr} \$ /$ ha nos tratamentos : sistema do agricultor (S.A.) e manejo de pragas (M.P.). Fätima do Sul-MS . 1982 ..

16 Comparação entre os custos de controle de tripes em $\mathrm{Cr} \$ /$ ha nos tratamentos: sistema do agricultor (S,A,) e manejo de pragas (M.P.), Fátima ào Sul - MS, $1982, \ldots . .$. 
.$x i$

17 Médias das percentagens de plantas infestadas por Tetranychus urticae (Koch, 1836) du rante o ciclo da cultura, com registro de precipitação pluviométrica no tratamento testemunha (T). Fátima do SuI - MS. 1982 .. 


\section{LISTA DE FIGURAS}

FI GURAS

Pâgina

1 Caminhamento para coleta de amostras de

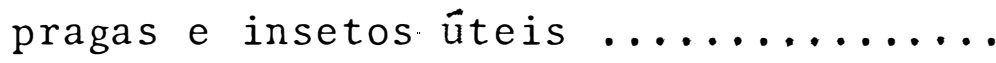

2 Médias das plantas infestadas em percen tagens por tripes nos tratamentos manejo de pragas (M.P.), sistema do agricul tor (S.A.), testemunis (T) com as pro dutividades obtidas. Fátima do Sul-MS. $1982 \ldots \ldots \ldots \ldots \ldots \ldots \ldots \ldots \ldots \ldots \ldots \ldots \ldots \ldots$

3 Niédias das plantas infestadas em percen a tagens por Aphis gossypii Glover, 1877 nos tratamentos: manejo de pragas (M.P.) sistema do agricultor (S.A.) testemunha (T). Fâtima do SuI - MS. $1982 \ldots \ldots \ldots$

4 Médias das plantas infestadas em percen tagens por Horcias nobilellus (Berg., 1843) nos tratamentos: manejo de pragas (M.P.), sistema do agricultor (S.A.), testemunha (T) com as produtividades ob tidas. Fätima do Sul - MS. 1982 ...... 
5 Médias das plantas infestadas em percen tagens por Helicthis virescens (Fabr., 1781) nos tratamentos: manejo de pragas (M.P.), sistema do agricultor (S.A.), testemunha $(\mathrm{T})$, com as produtividades obtidas. Fátima do Sul - MS. 1982.....

6 Médias das plantas infestadas em percen tagens por Tetranychus urticae (Koch, $1836)$ nos tratamentos: manejo de pragas (M.P.) sistema do agricultor (S.A.), tes temunha ( $\mathrm{T}$ ) com as produtividades obtidas . Fátima do Sul - MS, 1982 .......

7 Médias das plantas infestadas em percen tagens por Polyphagotarsonemus latus (Banks, 1904) nos tratamentos: manejo de pragas (M.P.), sistema do agricultor (S.A.), testemunha (T) com as produtivi dades obtidas. Fâtima do Sul - MS.1982.

8 Desfolha média causada por Alabama ar gillacea (Hueb., 1818) nos tratamentos, manejo de pragas (M.P.), sistema do agricultor (S.A.) e testemunha (T) com as produtividades obtidas. Fätima do Sul - WS, $1982 \ldots \ldots \ldots \ldots \ldots$ 
9 Médias das plantas infestadas em percen tagens por sirfídeos nos tratamentos : manejo de pragas (M.P.) sistema do agri cultor (S.A.) e testemunha (T). Fätima do $\mathrm{Su} 1-\mathrm{MS}$. $1982 \ldots \ldots \ldots \ldots \ldots \ldots$

10 Médias das plantas infestadas em percen tagens por Crisopíceos nos tratamentos: manejo de pragas (M.P.), sistema do agricultor (S.A.) e testemunha (T). Fátima do Sul - MS. $1982 \ldots \ldots \ldots \ldots$

11 Médias das plantas infestadas em percen tagens por Coccinelídeos predadores, nos tratamentos: manejo de pragas (M.P.), sistema do agricultor (S.A.) e testemunha (T). Fátima do Sul - MS. 1982 ....

12 Médias das plantas infestadas em percen tagens por orius sp. nos tratamentos: manejo de pragas (M.P.), sistema do a-. gricultor (S.A.) e testemunha (T). Fátima do Sul - MS. 1982 ......... 
13 Médias das plantas infestadas em percen tagens por Gecoris sp. nos tratamentos: manejo de pragas (M.P.), sistema do agricultor (S.A.) e testemunha (T). Fâtí ma do Sul - MS. 1982...............

14 Médias das plantas infestadas em percen tagens por Podisus sp. nos tratamentos:manejo de pragas (M.P.), sistema do agrıcultor (S.A.) e testemunha (T). Fátima do Sul - MS, $1982 \ldots \ldots \ldots \ldots$

15 Médias das plantas infestadas em percen tagens por Reduviídeos nos tratamentos manejo de pragas (M.P.), sistema do agricultor (S.A.) e testemunha (T).

Fätima do Sul - MS. $1982 \ldots \ldots \ldots \ldots$.

16 Médias das plantas infestadas em percen tagens por araneídeos nos tratamentos : manejo de pragas (M.P.) sistema do agri cultor (S.A.) e testemunha (T). Fâtima do Sul - MS. $1982 \ldots \ldots \ldots \ldots$

17 Fenologia e ocorrência de pragas do algodoeiro no tratamento testemunha. Fātima do Sul - MS. 1982 ........... 
18 Médias das plantas infestadas em percen tagens por Tetranychus urticae (Koch, 1836 ) durante o ciclo da cultura com registro de precipitação pluviométrica para Fátima do Sul no tratamento testemunha (T). Fátima do Sul - MS. 1982 ...

19 Linha de regressão e equação linear para a produtividade $x$ total de desfolha cau sado por Alabama argillacea (Huebner, 1818), acumulado no período dos 33 aos 112 dias da germinação do algodoeiro. Fátima do Sul - MS, $1982 \ldots \ldots \ldots \ldots \ldots$ 
.xvii. .

\section{LISTA DO . APENDICE}

APENDICE Página

1 Dados meteorológicos diārios do mês de outrubro de 1982. Fátima do Sul.

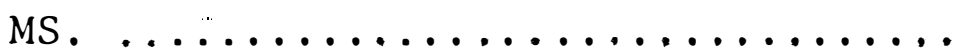

2 Dados meteorológicos diārios do mês de novembro ảe 1982, Fätima do Sul. MS. .....................

3 Dados meteorológicos diārios do mês de dezembro de 1982. Fátima do Sul.

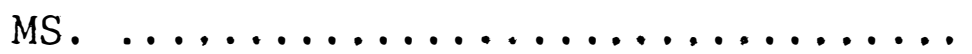

4 Dados meteorológicos diārios do mês de janeiro de 1983. Fätima do Sul. MS. $\ldots, \ldots \ldots \ldots \ldots \ldots \ldots \ldots \ldots \ldots$

5 Dados meteorológicos diārios do mês de fevereiro de 1983. Fätima do Sul. MS $\ldots \ldots \ldots \ldots \ldots \ldots, \ldots \ldots \ldots \ldots$ 


\section{VIABILIDADE DO MANEJO DE PRAGAS NA CULTURA \\ DO ALGODOEIRO EM FÁTIMA DO SUL-MS}

Autor: CARMO TOLEDO FERPAZ

Orientador: Prof. Dr. OCTĀVIO NAKANO

\section{RESUMO}

Com o objetivo de rerificar a viabilidade técnica e econômica de manejo de pragas do algodoeiro para a região de Fátima do Sul, MS, onde foram determinados os: níveis populacionais das pragas que afetam a produtividade, baseando-se nos custos dos tratamentos, instalou-se um experimento no ano agríco1a 1982/83. O plantio foi realizado em 1/10/1982, utilizando-se a variedade IAC-17. O experimento foi delineado em blocos casualizados e constou de 3 tratamentos: manejo de pragas, sistema do agricultor, testemunha (sem pulverização), com 3 repetições. Foi feita a amostragem das pragas e de seus inimigos na turais, 1 vez por semana, no período compreendido entre a germinação e aparecimento do primeiro botão floral e após a emissão do primeiro capulho, sendo que entre estes períodos mencionados as amostragens foram feitas 2 vezes por semana. No tratamento sistema do agricultor foram efetuadas 9 pulverizações, enquanto que no manejo de pragas, realjzaram-se apenas 3 aplicações 
mais 3 parciais correspondendo a uma redução no custo total de tratamento de $58 \%$. Os resultados obtidos permitiram concluir que: os níveis de controle observados e ajustados para as pragas da região em estudo não causam redução na produtividade do algodoeiro. O marejo de pragas proporciona uma redução drástica no número de aplicações de defensivos, preservando os inimigos naturais das pragas do algodoeiro, mostrando-se viâvel técnica e economicamente podendo ser recomendado aos cotonicultores da re gião. 


\title{
VIABILITY OF PEST MANAGEMENT ON COTTON CROP IN FÁTIMA DO SUL, STATE OF MATO GROSSO DO SUL, BRAZIL
}

\author{
Author: CARMO TOLEDO FERRAZ \\ Adviser: Dr. OCTÁVIO NAKANO
}

\section{SUMMIARY}

This research deals with the technical and economical viability of pest management on cotton crop in $\vec{r} \vec{a}-$ tima do Sul, State of Mato Grosso do Sul, Brazil. A field experiment to determine the population levels of the pests which affect the productivity, based on the costs of the treatments, was set in the agricultural year of $1982 / 83$. Cotton of the variety IAC-17 was planted on October 1st, 1982. The experiment was outlined in randomized blocks with 3 treatments: pest management, farmer's system and check (no spraying), and 3 replications. Samplings of the pests and their natural enemies were weekly done in the periodo from plant germination to the emergence of the first flower bud, and twice a week from this stage to the emission of the first cotton boll. The treatment farmer's system was sprayed 9 times while the treatment pest management received only 3 sprayings in the total area and 3 sprayings in parts of the area, which resulted in $58 \%$ reduction of the total cost of this second treatment. The 
results obtained allowed one to conclude that: the levels of control observed and adjusted for the pests of the studied region did not reduce cotton productivity; the pest management has provided a drastic reduction in the number of insecticide sprayings, thus preserving the natural enemies of the cotton pests and indicating to be technically and economically viable to be recommended to the cotton growers of the region. 


\section{INTRODUCAO}

No Brasil, a importância econômica da cultura do algodoeiro tem sido destacada em todos os trabalhos relacionados à cultura. De fato, alêm da obtenção de fibras têxteis ṇaturais, hâ a extração do ôleo comestivel das sementes que fornecem subprodutos para a alimentação animal.

Existem no país duas regiões distintas de produção: a região meridional onde se encontra a cultura do algo doeiro anual e a setentrional onde é cultivado o anual, e/ou semi-perene esta ültima compreendendo principalmente a ärea englobada pelo polígono das secas, apesar de ultimamente o cultivo de anual, nessa região, estar recebendo um acentuado incremento em termos de área cultivada (EMBRAPA, 1980).

No ano agrícola 1982/83, a produção mundial de algodão foi de 67,9 milhões de fardos de 480 libras, enquanto 
que a produção brasileira atingiu 3,2 milhões de fardos. Entre os Estados que mais se destacam, Mato Grosso do Sul ocupa o 5o lugar e na safra 1985/86 atingiu uma área plantada de 60.000 ha com um rendimento médio de $1.600 \mathrm{~kg} / \mathrm{ha}$ (SUMA AGRICO LA e PECUARRIA, 1985)

A inexistência da praga, o bicudo, Anthonomus grandis Boheman, 1843, a produtividade razoável e a boa renta bilidade para os produtores são os principais fatores responsáveis por este aumento no plantio.

Neste Estado, cultivo do algodão anual sem pre foi basicamente realizado por pequenos produtores, atin gindo a produtividade de até $3.000 \mathrm{~kg} / \mathrm{ha}$. Todavia, para o con trole dos artrópodos pragas (insetos e ácaros), as pulveriza ções de defensivos têm sido baseadas en um calendário prí-estabelecido, sendo ainda pouco difundido o manejo de pragas in troduzido recentemente em MS.

0 presente trabalho tem como objetivo verif car a viabilidade técnica e econômica deste novo modelo preco nizado por BLEICHER e FERRAZ (1980), onde se determinam os ní veis populacionais das pragas que afetam a produtividade baseando-se nos custos dos tratamentos. Alêrn disso, considera-se de fundamental importância a preservaçãodos parasitóides e predadores e os parâmetros climáticos que permitem prever surtos das pragas. 


\section{REVISAO DE LITERATURA}

\subsection{OS DEFENSIVOS NA LAVOURA ALGODOEIRA E SUAS CONSEQUENCIAS}

o controle químico teve seu início em 1870 com a descoberta do "Verde Paris" e progrediu rapidamente, com ou tros produtos inorgânicos muito perigosos.

A partir das leis de Mendel em 1900, as varieda des resistentes puderam ser melhor exploradas permitindo que algumas pragas se tornassem menos importantes. Mesmo assim nos ou tros anos houve um aumento no uso de produtos químicos (SMITH et alii, 1976).

Inúmeros compostos químicos surgiram durante a segunda Guerra Mundial e passaram a ser utilizados para a solução de vârios problemas relacionados com as pragas daquela época, pela boa eficiência fazendo com que houvesse um entusiasmo excessivo sobre esses produtos. 
Na agricultura, a utilização de defensivos quí micos tornou-se a maneira mais simples para solucionar o problema das pragas, sendo utilizado de modo indiscriminado. Entretanto, as repetidas aplicações passaram a exigir doses maiores e com maior freqüência. Houve o aparecimento da tolerân cia apresentada pelas pragas obrigando a substituição dos pro dutos usados por outros de maior efeito, que tambêm foram se tornando ineficientes; os insetos ressurgiam cada vez mais ra pịdamente após essas aplicações e muitos considerados secundá rios se tornaram sêrias pragas da agricultura. Dessa forma, os produtos químicos passaram a se $=$ mais um problema para o ho mem empenhado na atividade agrícola (LUCKMANN e METCALF, 1975).

A partir do momento em que a agricultura mundial se desenvolveu e tecnificou-se, o homem tem procurado con trolar todos os insetos que atacam a lavoura, especialmente a do algodão que apresenta sérios problemas com as pragas. A principal causa do fracasso àa cotonicultura numa região está diretamente vinculada à queda de produtividade e o principal motivo está relacionado com o ataque de pragas e aumento do consumo de inseticidas, onerando o custo da produção a ponto de tornar-se antieconômica (FALCON et alii, 1974). Este fenômeno ocorreu em várias partes do mundo tais como no Estado do Texas (USA), Nicarágua, México, Colômbia e Vale do Cañete no Peru.

No Brasil, em Santa Helena, Estado de Goiās, devido a isso, houve desestímulo e abandono da lavoura sendo 
que este município chegou a ser o maior produtor nacional de algodão (JIN e SILVA, 1978). Em Mato Grosso do Sul, em 1979, foi constatado que o mais grave problema enfrentado pelos cotonicultores era o controle de pragas (GIJLES et alii, 1979).

Naquela época, a média de aplicações, em todo o Estado era de 14 havendo regiões onde se faziam até 27 pulverizações (BLEICHER et alii, 1985). Estas aplicações eram feitas conforme Tabela 1 .

Em El Salvador, alterou-se seriamente o equilíbrio ecológico, havendo a necessidade de se recorrer a aplicações mais intensas para controlar as pragas. Como conseqüência deste desequilíbrio têm surgido raças resistentes de pragas como o bicudo A. grandis âlêm de estabelecerem-se como de primeira importância algumas pragas que anteriormente eram in significantes como a mosca branca Bemisia tabaci (Genn, 1889). Situações semelhantes ocorreram em outros países. Na Guatema1 a, por exemplo, se necessita aplicar entre 25 e 35 pulveriza ções, embora o ciclo da cultura seja bem maior em relação ao cultivo no Brasil, sendo que no início, vinte anos atrás eram necessârias apenas 8 pulverizações (GONZALEZ, 1977). No Estado do Texas, USA, do total dos inseticidas utilizados em todas as culturas, aproximadamente $50 \%$ eram destinados a cultura do algodão (ADKISSON, 1972).

Para melhor situar os problemas relativos ao $\underline{u}$ so indiscriminado dos inseticidas necessärio se torna mostrar a evolução da lavoura algodoeira classificada em 4 fases dis- 
Tabela 1. Esquema de pulverizações preventivas e produtos mais usados em MS. , 1979.

Número de Aplicações
Pragas visadas

Idade da Cultura

(Dias)

1. Tripes $\ldots \ldots \ldots \ldots \ldots \ldots \ldots \ldots \ldots \ldots \ldots \ldots \ldots \ldots \ldots \ldots \ldots \ldots \ldots \ldots \ldots, 7$

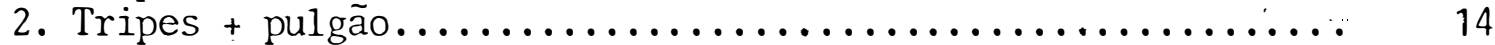

3. Tripes + pulgão...................................... 20

4. Pulgão + lagarta maçã................................ 30

5. Pulgão + curuquerê + lagarta maçã.................... 40

6. Curuquerê + lagarta maçã + ácaro rajado................. 50

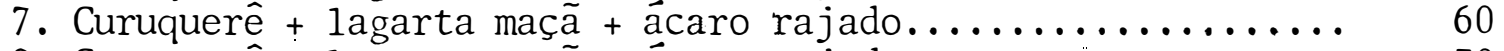

8. Curuquerê + lagarta maçã + ácaro rajado................ 70

9. Curuquerê + lagarta maçã + ácaro rajado + ácaro branco...... 78

10. Curuquerê + lagarta maçã + ácaro branco + lagarta rosada.... 85

11. Curuquerê + lagarta maçã + lagarta rosada............... 92

12. Curuquerê + lagarta maçã + ácaro rajado + ácaro branco + lagir $t a$ rosada..................................... 100

13. Curuquerê + lagarta maçã + àcaro rajado + ácaro branco + lagarta rosada.................................... 105

14. Curuquerê + lagarta maçã + lagarta rosada................ 120

Produtos mais usados (1 ou $\mathrm{kg} / \mathrm{ha}$ Dias

1. Dimetoato $(0,7)+$ Azodrin-60 $(1,0) \ldots \ldots \ldots \ldots \ldots \ldots \ldots \ldots . . .6 \ldots \ldots$

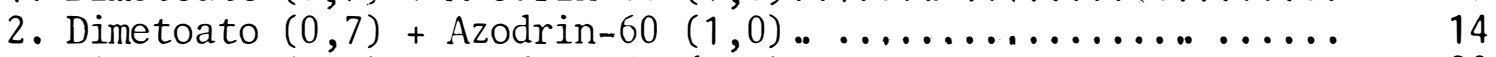

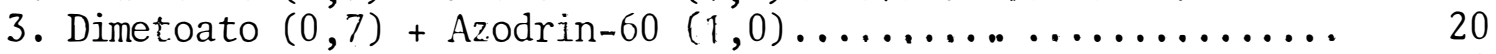

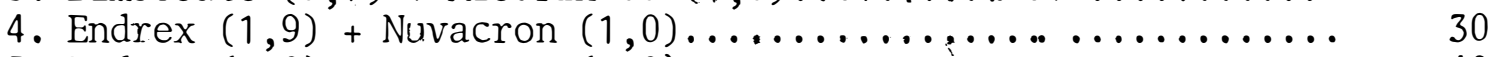

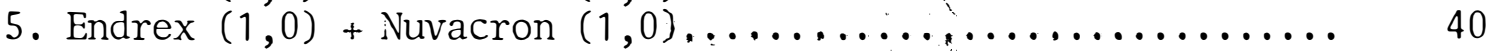

6 . Endrex $(1,0)+$ Nuvacron $(1,0)+$ Folidol $(1,0) \ldots \ldots \ldots \ldots \ldots . .6 . .60$

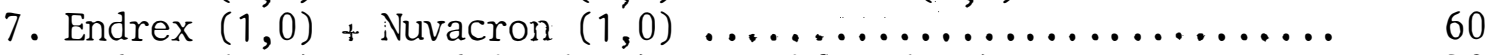

8. Endrex $(1,0)+$ Azodrin $(1,0)+$ Folidol $(1,0) \ldots \ldots \ldots \ldots \ldots . .6 \%$

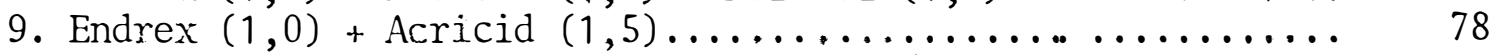

10. Endrex $(1,0)+$ Acricid $(1,5)+$ Folidol $(1,0) \ldots \ldots \ldots \ldots \ldots \ldots . .65$

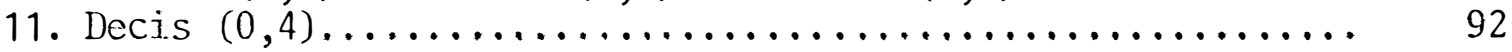

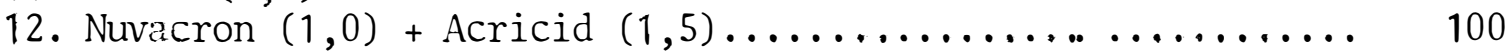

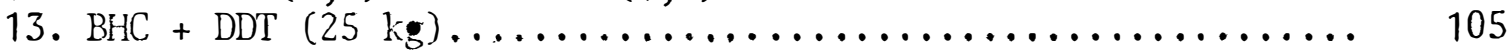

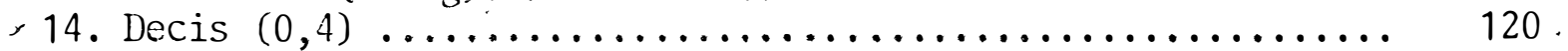


tintas:
a) fase de subsistência
b) fase de exploração econômica
c) fase de crise
d) fase de desastre

Esta ûltima diz respeito ao total desaparecimen to da cultura na região sendo necessária a implantação de um novo conceito de controle, razão pela qual o manejo foi instituído (BOTTRELL e ADKISSON, 1977).

\subsection{MANEJO DE PRAGAS E SEUS PRINCÍPIOS}

Tornou-se urgente a necessidade de uma tecnolo gia mais racional para uma melhor adequação dos problemas relacionados com as pragas.

GEIER e CLARK (1961) idealizaram um esquema para o manejo das populações das pragas.

GEIER (1970) sugeriu o termo Manejo de Pragas para expressar em bases ecológicas o controle das pragas.

KOGAN (1980) citou que o manejo de pragas é a combinação na medida do possível, de diferentes métodos de controle, de uma forma harmoniosa que favoreça os interêsses $\underline{e}$ conômicos, ecológicos e sociais.

o manejo de pragas $\ddot{e}$ neste caso um meio pelo qual se utilizam todas as técnicas disponiveis para a redução das populações de insetos-pragas, sem a preocupação da erradi 
cação das espécies, pois é importante mantê-las a níveis tole räveis para permitir a sobrevivência dos inimigos naturais.

Os insetos, em condições naturais e em um siste ma ecológico, tem sua população equilibrada em função de vârios fatores ambientais adversos à sua multiplicação e também atra vés de seus inimigos naturais que impedem o aumento de sua po pulação.

Dessa forma, o manejo de pragas é caracterizado pelos seguintes aspectos:

a) Preocupa-se com o nível de dano toleracio e não com a erradicação da praga.

b) Leva em consideração os fatores bióticos e abióticos que são agentes de controle natural.

c) A medida de controle adotada deve favorecer os fatores naturais de repressão da praga visando manter a sua população em níveis inferiores ao nível de dano econômico, com o objetivo de se obter máxima produtividade e qualidadeda produção, mínimos custos e ausência de resíduos na alimentação, evitando-se desequilíbrios ecológicos (SILVA et alii, 1981).

o nível de dano econômico (NDE) é a densidade populacional de uma espécie de inseto que causa um prejuízo a cima do custo de controle, sendo este ainda economicamentevia vel. A partir do nível populacíonal cujo dano seja equivalente ao custo do tratamento a espécie será considerada praga. o nível de controle (NC) será então a densida- 
de populacional onde devem ser adotadas medidas para impedir que o inseto atinja o nível de dano econômico.

Nível de equilíbrio (NE) jā reflete a população média do inseto na lavoura sem causar dano significativo. o nível de controle pode ser obtido através da fórmula:

$$
\because \mathrm{D}=\frac{\mathrm{Ct} \times 100}{\mathrm{~V}} \text { onde: }
$$

$\because \mathrm{D}=$ percentagem de dano que corresponde à de terminada densidade populacional do inseto (Nível de dano)

$C t=$ custo de controle/ha

$\mathrm{V}=$ valor da produção

Estes níveis são obtidos experimentalmente pa् ra cada cultura e para cada praga em particular (NAKANOetalii, 1981).

Para HEADLEY (1973), o manejo de pragas leva em conta a complexidade do agroecossistema no qual um sistema de amostragem indica se a praga atingiu o indice populacional tal que justifique a intervenção do agricultor com uma ou mais medidas de controle.

Estas medidas deverão causar um menor distúrbio possível sobre a fauna e flóra benéfica resultando no menor nümero de pulverizações e conseqüentemente maior margem de lucro ao agricultor. 
LUCKMANN e METCALF (1975) afirmam que são inesgotảveis os métodos de controle de pragas. Entre eles destacam-se:

1. Métodos mecânicos

2. Métodos físicos

3. Métodos culturais ou práticas agronômicas

4. Métodos biológicos

5. Mêtodos químicos

6. Métodos genéticos

7. Métodos regulatórios

\subsection{CONTROLE QUímico e Biológico}

Conforme afirma DeBACH (1974), é raro o organismo que não tenha o seu inimigo natural, e a aplicação dos pricípios ecológicos básicos aos problemas das pragas poderá reduzir o uso de defensivos no agroecossistema, pois, o uso intensivo e extensivo de produtos químicos como única medida de controle acarreta sérias conseqüências.

A ressurgência de pragas, o desequilíbrio bio lógico e o desenvolvimento de resistência das pragas cada vez maior aos defensivos mostra nitidamente a urgente necessidade em buscar outros métodos de controle de uma maneira econômica eficiente e ecológica. Para exemplificar, o mesmo autor cita que na década de 50, no Vale do Rio Grande no Texas, as pra- 
gas do algodoeiro foram combatidas durante aproximadamente 15 anos utilizando-se de produtos clorados as quais se tornaram resistentes a estes produtos.

Passaram então a usar os organo-forforados especialmente o metil-parathion e como conseqüência novas pragas como a lagarta da maçã Heliothis virescens (Fabr., 1781) que naquela época era considerada inexpressiva passou a ser a praga mais prejudicial que o próprio bicudo do algodoeiro. Foi então empregado o DDT para o seu controle e em 1962 esta praga já era resistente a värios clorados, inclusive o DDT, e aos carbamatos sendo que, em alguns casos, ainda se podia controlá-la com elevadas doses de metil-parathion.

A utilização em larga escala dos inseticidas carbaryl e parathion produziu aumentos nas populaçóes de äcaros Tetranychus spp., outra prova evidente dos problemas com o uso de produtos químicos, O mesmo autor cita ainda que, em 1965 hou ve explosão populacional de Pectinophora gossypiella (Saund., 1844).e para seu controle procedeu-se de uma forma precipitada utilizando os defensivos com amplo espectro de ação a cada seis dias, com a finalidade de sua eliminação total e rápida. Devido a isso houve o aumento de outras pragas que se torna ram danosas fazendo com que as lavouras se tornassem improdutivas. OLIVEIRA e VERCESI (1983) realizaram trabalhos afim de avaliar o efeito de produtos piretróides sobre a população do ácaro rajado, Tetranychus urticae (Koch, 1836), na cultura do algodoeiro. Os tratamentos foram: fenvalerate; cypermethrim, 
Os tratamentos foram: fenvalerate, cypermethrim deltamethrin, permethrin, metil-S-demeton + monocrotophos + cada um dos piretrôides citados, testemunha. Os autores concluiram que os piretróides causaram um acentuado aumento da população de $T$. urticae e que as pulverizações desde a fase inicial da cultura causam um maior aumento das infestações.

Entretanto SETTEN et alii (1982) avaliaram o efeito de vârios produtos químicos sôbre a taxa de oviposição de fêmeas de T. urticae, em condições de laboratório, com os seguintes tratamentos: parathion metilico, oxicloreto de cobre, deltamethrin, cypermetrin, fenvalerate, fenvalinate, tes temunha. Foi observado que a mêdia de ovos por dia não diferiu estatísticanebte da testemunha não acarretando portanto aumento na população de âcaros.

NAKANO e PEREZ (1981), realizando experimentos no município de Guaíra (SP) nos anos de 1977/78 e 1978/79, ve rificaram que o uso de piretróides na cotonicultura permite uma maturação precoce dos frutos e que a deiscência dos mesmos se dá de forma mais uniforme quando em comparação com outros inseticidas .

RENOU e DELATTRE (1981) constataram que o em prego de piretróides na cultura do algodäo acelera a maturação, antecipando a colheita.

$$
\text { Sparks (1981) e Wolfenbarger et alii. }
$$
citados por ROUSH e WOLFENBARGER (1985), relataram que a 1 agarta da maçã é uma importante praga do algodão e de outras 
culturas nos Estados Unidos sendo feito largamente o uso de inseticidas para o seu controle e a resistência aos inseticidas tem se constituído em sério p̣roblema.

$$
\text { Martinez-Carrilo e Reynolds (1983) citados pe }
$$

los mesmos autores afirmamque altos níveis de resistência tem sido apresentados por raças mexicanas de $H$. virescens na Califórnia.

Entretanto, STAETZ (1985) avaliou a susceptibí lidade de populações de H.virescens no período de 1979 a 1983 ao piretróide permethrin, concluindo que não houve o desenvolvimento de resistência desta praga ao inseticida testado. HUFFAKER (1975) comenta que num agroecossistema o controle biológico natural é o responsável pelo equilí brio da natureza o qual é ignorado pelo homem e que esse "invisível" controle se compara a um "iceberg", sendo que a parte menor corresponde às pragas que o controle biológico não conseguiu controlá-las e a parte maior, imersa, aproximadamen te igual a $2 / 3$ de seu tamanho, representa os insetos mantidos em equilíbrio pelos inimigos naturais.

EHLER (19.77), com a finalidade de mostrar a eficiência do controle natural montou a tabela de vida da praga Trichoplusia ni (Hueb, 1802), onde observou-se a ação de parasitos, predadores e patógenos em conjunto desde a postura da praga até a emergência, onde mais de $96 \%$ da população foi eliminada pelos inimigos naturais.

BISHOP e BOOD (1977) verificaram na cultura do 
algodoeiro a existência de 61 espécies de inimigos naturais sendo 44 espécies de 20 famílias de predadoras, 13 espécies de famílias parasitas e 4 entomopatögenas. Das espécies identificadas, 31 atuam reduzindo o complexo Heliothis spp. no campo. Observaram ainda que das 22 espécies de aranhas que ocorreram, 8 espécies são predadoras de lagaxtas das maçãs, He liothis spp.

SUEKANE e WASSANO (1982), com o objetivo de um melhor conhecimento dos inimigos naturais das pragas na cultu ra algodoeira, realizaram trabalhos em Navirai-MS. Os levanta mentos foram feitos de 1 a 2 vezes por semana a partir dos 39 dias até aos 116 dias da semeadura, amostrando-se 100 plantas. A área foi cultivada com a variedade IAC-17, sendo as sementes tratadas com orthene+brassicol. Os principais inimigos na turaic encontrados em quantidades elevadas foram: coccinelídeos, araneídeos, Geocoris sp., Chrysopa sp., Orius sp., Campoletis sp. sendo em menores quantidades sirfideos, taquinideos, Euplectrus sp., Calosoma sp., Podisus sp.

As maiores populações destes artrópodos concen traram-se em torno de 85 a 90 dias quando as populações de $A$ labama argillacea e Heliothis spp. eram elevadas.

Concluem os autores que os inimigos naturais surgem em função das pragas e que com o uso de defensivos não seletivos ou o seu emprego antecipado sem necessidade prejudi ca o trabalho gratuíto proporcionado pela entomofauna benéfica . 
NAKAYAMA e.t alii (1982) encontraram em MS nos municípios de Deodápolis, Taquarussu e Fátima do Sul, o parasitóide Trichogramma spp. em ovos de A. argillacea com picos de parasitismo de $79,85,82 \%$, respectivamente.

JESUS et alii (1984) comentaram que pesquisas preliminares mostram-se promissoras no que diz respeito ao uso de Trichogramma spp. no controle biológico de A. argillacea.

FALCON (1971) indica que, para o desenvolvimento do manejo de pragas, também é necessário acelerar pesquisas visando seletividade ecológica de inseticidas.

GRAVENA et alii (1985) realizaram ensaios vi sando testar a eficiência de chlorpyrifós e dimetoato para Aphis gossypii Glover, 1877 e avaliar a seletividade desses produtos a coccinelídeos earaneídeos. Foi verificado que chlorpyrifós apresentou os melhores resultados no controle do pulgão sendo que o dimetoato também mostrou resultados satisfatō rios e com maior seletividade para coccinelídeos.

BLEICHER et alii (1984) concluíram que o uso de demeton metilico na dosagem de $65 \mathrm{~g}$ do i.a. por hectare tem alcançado bons resultados no controle do pulgão, deixando intacta populações de sirfídeos, crisopídeos, coccinelídeos e etc.

\subsection{PERSPECTIVAS DO MANEJO DE PRAGAS}

BEINGOLEA (1980) cita que para a implantaçãoc 
desenvolvimento do Manejo de Pragas sãonecessários conhecimen tos básicos sobre:

a) Biologia, fisiologia e ecologia das pragas e de seus inimigos naturais.

b) Fenologia da cultura

c) Principais fatores bióticos e abióticos do ambiente que regulam as flutuações populacionais da praga.

d) Impacto dos métodos de controle sobre as po pulaçóes das pragas e de seus inimigos biológicos.

e) Sistemas de amostragens rápidos e sčuıros que permitam tomar uma decisão sobre a aplicação de uma medida de controle

f) Anâlise da relação custo-benefício do trata mento.

FERREIRA (1980) montou um campo correspondente a 2 áreas com 1 ha cada para estudos comparativos do controle de pragas entre os métodos tradicionais do produtor rural e o preconizado pelo manejo de pragas. O autor verificou que no cômputo geral, o campo de manejo rendeu vinte arrobas a mais por hectare, além da economia verificada na redução do número de pulverizações (quatro aplicações na área do manejo, contra sete na ảrea do produtor). Provavelmente, a maior produção na ärea do manejo se deveu aos danos mecâninicos causados pelo trator que foi utilizado 3 vezes a mais na área do agricultor, alëm de 
outros fatores.

FERRAZ e BLEICHER (1982) relatam que em MS os cotonicultores assistidos diretamente pela EMPAER reduziram a média de pulverizações de 12,19 para 4,72, quando efetuaram o controle de pragas baseado em amostragens onde as pul verizações eram feitas somente quando as pragas atingiam o nível de controle.

Devido às misturas e altas dosagens desnecessárias usadas pelo produtor o custo médio de cada pulverização, foi do Cr\$2.547,00/ha enquanto que nas äreas de manejo o cus to foi de $\operatorname{Cr} \$ 1.844,00 /$ ha. Desta forma, concluem os autores que houve uma economia de $72 \%$, para aqueles que adotaram o manejo de pragas.

CRUz (1982) menciona que, em Santa Cruz das Palmeiras, os produtores, nas safras 1980/81 e 1981/82, passaram a aplicar defensivos na cultura algodoeira conforme recomendações do manejo de pragas e fazendo o uso de sementes tra tadas com inseticidas sistêmicos, chegando a reduzir as aplicações para uma apenas, sem perda na produtividade.

ELIAS e ORTEGA (1965) avaliaram no Valle del Yaqui, no México, o efeito de 2 programas de tratamentos de pra gas, (com 7 e 4 pulverizações) não sendo realizado o tratamen to das pragas tardias a partir da abertura dos primeiros frutos. Pelos resultados obtidos concluiram que a parcela teste munha (sem defensivos) foi a que alcançou maior lucro. Estes dados contribuiram para refutar a idéia que tinham alguns téc 
nicos e agricultores de que pulverizações com antecipação de úm mês antes da colheita, para o controle de pragas tardias acarreteriam aumentọs nạ prợuçãọ, mesmo em baixas populações.

Os autores relatam ainda que a região do Valle del Yaqui, em sua maior parte, se pode considerar com escassos problemas de pragas, onde nas condições em que foram realizados os experimentos nenhum inseto atingiu o nível de controle e que o mais conveniente é orientar o controle das pragas baseando-se no nível de infestação fornecido por amostragens oportunas e adequadas.

\subsection{ESTABELECIMENTO DOS NÍVEIS DE CONTROLE}

Para Mato Grosso do Sul poucos trabalhos tem sido feitos visando o desenvolvimento de técnicas de manejode pragas. BLEICHER e FERRAZ (1980) sugeriram de forma pioneira, a aplicação de um esquema de manejo de pragas com base em conhecimentos que jầ vinham sendo utilizados em outros Estados.

\subsubsection{RECOMERDACŌES GERAIS}

\section{$2 \cdot 5 \cdot 1 \cdot 1$. USO DE INSETICIDAS NO INICIO DO CICLO \\ o uso indiscriminado de defensivos no iníciodo} cultivo pode afetar de forma drâstica a ação dos inimigos naturais. 
Populações iniciais de tripes e pulgões servem de fonte de alimento para os predadores que mais tarde irão se alimentar de ovos e larvas de Heliothis spp. entre outras. 0 excesso de inseticida nessa época não só irâ eliminar os in setos benéficos bem como diminuir sua fonte de alimentos, fazendo com que morram ou migrem deixando futuras populações de Heliothis spp, e outras pragas, livres do controle natural. Por tanto, deve-se escolher para o início do cultivo inseticidas de curto efeito residual para possibilitar a multiplicação dos inimi ${ }^{n s}$ naturais, alêm de não exigir do mesmo $100 \%$ de controle das pragas para alimentar aqueles insetos predadores da lagarta da maçã sendo os mais comuns orius spp., Geocoris spp., Nabis spp., coccinelídeos, reduviídeos, aranhas etc. Entreos principais predadores de pulgões destacam-se: coccinelídeos, sirfídeos e crisopídeos.

\section{5 .1 .2 REBOLEIRAS}

E comum o ataque de pragas em reboleiras ou manchas na lavoura. O controle químico nestas reboleiras é eficiente e econômico pois, o defensivo estarả sendo aplicado de uma forma seletiva, preservando os inimigos naturais, com menor custo e menor poluição

2.5.1.3 FREQÜENCIA DE AMOSTRAGENS DAS PRAGAS E INIMIGOS NATURAIS

a) Da germinação ao aparecimento dos primeiros 
botões florais é feita uma vez por semana.

b) Do aparecimento dos botões florais até ao aparecimento do primeiro capulho: duas vezes por semana.

c) Após os primeiros capulhos, uma vez por semana .

Quando o nümero de determinada praga estiver próximo ao nível de controle, deve-se fazer amostragem com maior freqüência.

0 tamanho da área não deve exceder a 10 ha. Quan do existirem áreas maiores corvém dividí-1as em áreas de apro ximadamente 10 ha, procurando nesta divisão torná-las o mais homogêneas possível quanto à fertilidade, umidade do solo, declividade, etc. Quando da existência de áreas muito extensas e contínuas, deve-se estratificá-las e proceder várias amos tragers tentando estimar da melhor maneira a população das pra gas existentes.

\section{$2.5 \cdot 1.4$. CAMINHARENTO}

Para a tomada de amostras, o caminhamento deve ser de forma que represente toda a área, sendo escolhidas 45 estações de amostragens, examinando-se em cada uma delas no ponteiro da planta e anotando-se os insetos em ficha de campo própria para este fim. 


\section{5 .1 .5 . MEDIDAS CULTURAIS}

a) Limpeza do campo após a colheita mediante o arranquio e queima das soqueiras, seguindo-se de aração e gra deação do solo;

b) rotação de cuituras usando-se amendoim, mi1ho, entre outras;

c) plantio na época recomendada pela pesquisa;

d) controle das plantas daninhas, principalmen te daquelas que abrigam as pragas da cultura.

\subsubsection{RECOMENDACÕES ESPECÍFICAS}

\subsubsection{BROCA DO ALGODOEIRO - Eutinobothrus brasiliensis (Hambleton, 1937)}

Em lugares onde sua ocorrência é freqüente, su gere-se o controle químico preventivo e medidas culturais de controle. No caso de plantas provenientes de sementes tratadas com inseticidas estas devem receber uma aplicação do defensivo logo após o desbaste

\subsubsection{TRIPES DO ALGODOEIRO - Thrips spp., Hercothrips spp., Frankliniella sp.}

Esta praga deve ser controlada somente até aos 15 dias após a germinação, no caso de elevadas infestações con provadas por amostragens ou seja, quando forem encontrados em mé- 
dia dois ou mais tripes por folha. Geralmente em caso de sementes tratadas com inseticidas sistêmicos não hā necessidade do controle, entretanto deve-se fazer amostragens periódicas. Em plantios antecipados, quando ainda ocorrem dias frios, pode haver um maior ataque.

SATO et alii (1984) mostraram que autilização de sementes tratadas no plantio com os inseticidas sistêmicos Marsha1, Disyston e Furadan apresentaram cerca de 70 a $80 \%$ de eficiência de controle dos tripes até aos 15 dias após a emer gência.

SANTOS (1982) comentou que; no estado do Paraná, a maior densidade populacional como também a maior intensi dade de danos às plantas tem-se verificado aos 20 dias da emergência e que, após os 30 dias a população diminue sensive mente. O autor afirma ainda que em plantios efetuados com se mentes tratadas a cultura é protegida por até 30 dias após a eme gencia contra o ataque de tripes e que a utilização de defensivos após o estabelecimento de altas populações, no iníciode desenvolvimento do algodoeiro, não é suficiente, muitas vezes para evitar danos significativos na produção.

\subsubsection{PULGÃO DO ALGODOEIRO - Aphis gossypii Glover, 1877.}

Esta praga a parece no início do cultivo. Ela è de vital importância no manejo das pragas... A aplicação indiscriminada de defensivos contra o pulgão irá romper o equi- 
líbrio biológico, fazendo com que a lagarta da maçã se torne mais problemática.

A população desse afídeo é regulada por um grande número de inimigos naturais. O controle deverá ser fe $\underline{i}$ ťo quando atingir 70\% de plantas atacadas, com infestações de aproximadamente 20 ou mais pulgôes por folha. Caso tenhamos mais de $70 \%$ de plantas atacadas, porém com a presença de $20 \%$ de crisopídeos, coccinelídeos, ou larvas de sirfídeos não deverá ser feita a pulverização voltando-se a fazer outra amostragem após dois dias para nova decisão.

SANTOS (1980) concluiu que esta praga atinge maiores infestações até aos 50 dias da emergência, reduzindose em seguida; ressalta ainda que com o uso de sementes trata das com inseticiảas sistêmicos mantêm-se a incidência em níveis baixos em até 20 vezes menos em relação às sementes não tratadas.

0 autor também relata ainda que é necessária al tíssima população para que haja reflexos na produção, sendo que apenas uma infestação acima de 20 pulgões por folha poderá di minuir os rendimentos da cultura,

2.5.2.4. CURUQUERE DO ALGODOEIRO - Alabama angillacea (Huebner, 1818).

Em cada estação estima-se a percentagem média de desfolha provocada pelo curuquerê para três folhas em di- 
ferentes alturas.

Controlar a praga quando a percentagem média de desfolha nas 45 estações for:

a) $50 \%$ do período da germinação ao aparecimento dos primeiros botões florais;

b) $25 \%$ do período do aparecimento dos primeiros botões florais a deiscência do primeiro fruto;

c) $50 \%$ após a deiscência do primeiro fruto.

MARUR e SANTOS (1980 verificaram que até aos 110 dias após a emergencia a pirdução é reduzida somente em níveis superiores a $33 \%$ de desfolha. Após os 110 dias houve redução nos rendimentos somente para desfolhamentos em níveis acima de $66 \%$

\subsubsection{5. ÁCARO RAJADO - Texranychus wrticae $($ Koch, 1836).}

Esta praga aparece principalmente em periodos cos. O tratamento das reboleiras é indicado para esta praga.

Se o äcaro mostrar ataque generalizado efetuar o controle com produtos específicos, quando foram encontrado em média, nas 45 estações, $10 \%$ de plantas com sintoma inicial de at aque.

Segundo NICKEI (1960), a temperatura, unidade e precipitação podem influir na severidade dos danos, no de- 
senvolvimento das populações e na distribuição geográfica das espécies.

CHIAVEGATO (1971) mostrou que hả influência do clima na população do ácaro rajado, que em condições de alta precipitação pluvial, há uma redução nas infestações, re velando que a chuva exerce um bom controle natural. A explicação para isso deve ser a ação direta da ägua sobre os ảcaros (efeito de lavagem:).

REIS, (1972) também observou maiores infestações durante o periodo de baixa precipitação pluvial.

FURR e PFRIMMER (1968) concluiram que o algodoeiro precisa de proteção contra este ácaro somente até quando as primeiras maçãs atingirem $2 \mathrm{~cm}$ em diâmetro, (infestações tardias).

NAKANO (1980) relatou que a fase crítica para a incidência de T. urticae vai até aos 90 dias e que dessa época em diante não significa qualquer diferença na produção.

\subsubsection{6. ĀCARO BRANCO - Polyphagotarsonemus latus (Banks, 1904)}

0 ataque ocorre nas folhas novas do ponteiro, dando-1hes um aspecto brilhante e coriäceo com as margens dobrando-se para cima, e finalmente em ataques mais intensos ras gam-se pela ação do vento. O controle também deverá ser feito nas reboleiras iniciais. O tratamento de toda a lavoura é fe 
to quando for detectada um média, $40 \%$ de plantas com sintomas de ataque nas 45 estações.

\subsubsection{LAGARTA DAS MACCAS-Heliothis virescens (Fabr., 1781)}

O controle deverá ser realizado quando forem constatados $10 \%$ de plantas com a presença de larvas nos botões florais.

Foi observado aue na fase de lua nova há uma maior atividade das mariposas $\epsilon$ :onseqüentemente maior ovipos tura. Deve-se anotar também os ovos, pois dessa forma pode-se ficar alerta para possiveis explosões populacionais.

0 período crítico para o controle desta praga, é de 80 a 115 dias

SANTOS. (1979) simulou o ataque de lagartas em níveis de destruição de estruturas frutíferas de 33, 66 e $100 \%$ retirando-as ao longo dos ramos de baixo para cima, através dos seguintes sistemas: ao nível de $33^{\circ}$, tira-se uma estrutura e deixam-se duas enquanto que ao nível de 66\% são retiradas duas deixando-se uma. 0 autor observou que, em plantios mais cedo, dentro do período recomendado, houve diminuições sen síveis na produção a partir dos 97 dias para as simulações de danos a nível de $33 \%$ e dos 86 dias para os níveis de 66 a 100\%.

Para o ensaio cuja emergência se deu tardiamente ( 12 de novembro), as simulações de danos ao nível de $33^{\circ}$ afetaram significativamente a produça a partir dos 86 dias, 
enquanto que para os níveis de 66 a $100 \%$ o rendimento foi afetado jā a partir das simulações realizadas aos 73 e 64 dias respectivamente. Estes resultados indicam a importância da época de plantio pois quando tardiamente há diminuição do período de frutificação e conseqüentemente menores condições de recuperação.

\subsubsection{LAGARTA FALSA MEDIDEIRA-Trichoplusia ni (Hubner, 1802)}

E de ocorrência esporádica na cultura do algodoeiro. Em condições de grandes estiagens pode vir a ser problema, no entanto, nas condições normais, é controlada por inimigos naturais. O nível de controle é o mesmo sugerido para o curuquerê.

\subsubsection{LAGARTA ROSANA - Pectinophora gossypiella} (Saund., 1844)

Deverā ser feita a abertura de uma maçã em fase de endurecimento por estação na parte média da planta pa ra verificar a presença da larva.

Deverā ser controlada quando forem encontradas $6 \%$ de maçãs atacadas.

Plantações antecipadas são menos infestadas por esta praga. 
Segundo Adkisson e Dyck (1980), citados por VENDRAMIM, (1984), esta praga pode ser controlada por präticas culturais as quais visam reduzir o número de indivíduos em dia pausa, o que envolve o plantio mais cedo e uniforme, a maturação precoce, desfolha e destruição das soqueiras antes que as lagartas entrem em diapausa pela ocorrência de dias curtos e noites frias.

SANTOS (1984) concluiu que, em plantios mais tardios, hä maior ataque da lagarta rosada tornando-se difícila eficiência do controle químico nestas condições.

\subsubsection{PERCEVEJO RAJADO Horcias nobilellus (Berg., 1883 ;}

0 ataque desta praga coincide com o aparecimento dos botões florais. O nível de controle é de $20 \%$ de plantas atacadas. A amostragem é feita no ponteiro onde se contam ninfas e adultos. 


\section{MATERIAL E MÉTODOS}

\subsection{LoCALIZAÇ̃o e PLANTIO}

$\therefore \quad 0$ ensaio com a cultura do algodoeiro foi insta lado na propriedade rural do Sr. Benedito Assunção, no municí pio de Fátima do Sul, Estado de Mato Grosso do Sul, no ano agrícola 1982/83, utilizando-se a cultivar IAC-17.

0 plantio foi realizado no dia $01 / 10 / 1982$, ocorrendo a germinação no dia $08 / 10 / 1982$.

A adubação de manutenção foi de $200 \mathrm{~kg} / \mathrm{ha}$ da fôrmula 4-30-10, baseando-se na análise de solo do local (Tab. 2). O espaçamento foi de $1,10 \mathrm{~m}$ entre fileiras, sendo o desbas te feito aos 25 dias da germinação deixando-se 5-6 plantas por metro-1inear. 


\subsection{DeLinEAMENTO EXPERIMENTAL E tRATAMENTOS}

O experimento foi delineado em blocos casualizados e constou de 3 tratamentos:

- Tratamento 1 - Sistema do agricultor (S.A.) Neste procurou-se fazer o controle das pragas conforme o calendário utilizado pelo produtor, mantendo-se o tratamento livre de pragas, através de constantes pulverizações. As sementes empregadas não foram tratadas com inseticidas.

- Tratamento 2 - Manejo de pragas (M.P.)

As sementes foram tratadas com inseticidas sis têmico dissulfoton. As pragas foram controladas somente quando atingiam o nível de controle seguindo-se as recomendações de BLEICHER e FERRAZ (1980).

- Tratamento 3 - Testemunha (T)

Nesta parcela as sementes utilizadas para o plantio também não foram tratadas e neṇum controle foi feito para as pragas.

Foram utilizadas 3 repetições, ficando estabelecido o croqui abaixo:

\begin{tabular}{|c|c|c|}
\hline S.A. & T. & M.P. \\
\hline T & M.P. & S.A. \\
\hline M.P. & S.A. & T. \\
\hline
\end{tabular}


Cada parcela teve uma área de 0,5 ha ficando entre cada uma delas um espaço de 2 m cultivadas com 5 fileiras de milho.

Os custos de controle foram calculados segundo os preços de produtos e mão-de-obra verificados em março de 1983.

\subsection{AMOSTRAGENS DAS PRAGAS E INIMIGOS NATURAIS}

As pragas de importância econômica e os inimigos naturais amostrados encontram-se nas Tabelas 3,4 e 5 .

As amostragens foram feitas conforme recomendação BLEICHER e FERRAZ (1980) e o caminhamento para o tomada das amostras foi o preconizado pelo INTA (Guia para el recono cimiento de pragas del algodon e insectos utiles) da Argentina, conforme figura 1., com alternação a cada semana no sentí do do caminhamento, sendo 1 vez por semana da germinação ao a parecimento do primeiro botão floral e tambẻm após a deiscência do primeiro fruto. Entre o aparecimento do primeiro botão floral e a deiscência do primeiro fruto foi feita 2 vezes por semana.

Os insetos referentes a cada ponto de amostragem foram anotados em ficha de campo própria para tal finalidade.

Para a avaliação das pragas foi considerado per 
centagem de plantas infestadas e percentagem de plantas com presença de inimigos naturais. Para A. argillacea foi conside rado a percentagem de desfolhamento.

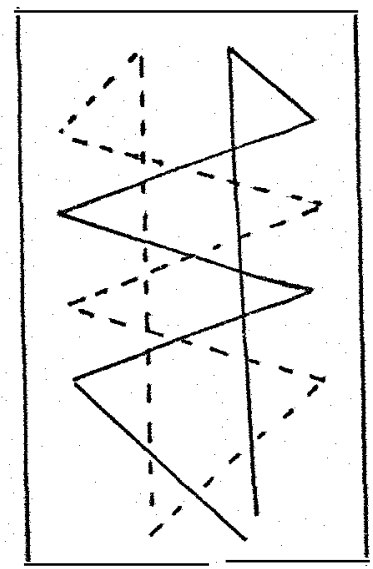

Figura 1. Caminhamento para coleta de amostras de inimigos naturais.

\subsection{COLHEITA}

Foram realizadas duas colheitas manuais sendo a primeira em 12/02/1983 e a segunda no dia 23/02/1983. Para a colheita foram tomadas em cada parcela 20 amostras de $5 \mathrm{~m}$ 1ineares nas fileiras de plantio. O algodão em caroço foi acondicionado em sacos de papel para a pesagem.

\subsection{DADOS METEOROLÓGICOS}

Foram fornecidos pela Embrapa e estão relacionadas no apêndice. 
Tabela 2. Análise de solo do local do experimento FÂTIMA DO SUL-MS 1982

\begin{tabular}{cccccc}
\hline & m.e. $/ 100 \mathrm{~cm}^{3}$ de & T.F.S.A. & & \multicolumn{2}{c}{$\mathrm{PPNi}$} \\
\cline { 1 - 2 } $\mathrm{pH}$ & $\mathrm{Al}^{+++}$ & $\mathrm{Ca}^{++}+\mathrm{Mg}^{++}$ & & $\mathrm{P}$ & $\mathrm{K}^{+}$ \\
\hline 6,2 & 0 & 8 & 10 & +200 \\
\hline
\end{tabular}

\subsection{ANÁLISE ESTATISTIICA}

Os dados de produtividade, plantas infestadas por pragas, o de desfolhamento e presença de inimigos naturais foram submetidos a anâlise de variancia e Teste de Tukey. Para o estudo da relação entre produtividade e percentagem de desfolhamento de plantas realizou-se uma regressão com dados acumulados de desfolha no período entre 33 a 112 dias da germinação. Foi feito ainda o cálculo de correlação entre as populações de ácaro rajado e precipitação pluvial. 


\section{RESULTADOS E DISCUSSÃO}

\subsection{AMOSTRAGEM DAS PRAgas E INIMIgOS naturais}

Os dados obtidos sobre a ocorrência de pragas e inirigos naturais nos diferentes tratamentos encontram-se nas Tabelas 3,4 e 5 com suas anâlise de variância nas Tabelas 7 e 9 .

Estes dados foram utilizados na elaboração das figuras de nüneros 2 a 16 da figura 17 onde constam a fenologia e ocorrência das pragas do algodoeiro observada na região em estudo.

Pelo exame das tabelas 3,4 e 5 e suas análises estatisticas nas tabelas 6 e 8 verificou-se que houve diferença estatística significativa entre as plantas infestadas pelo pulgão, percevejo rajado Horcias nobilellus (Berg., 1883) e a desfolha provocada pelo curuquerê nos tratamentos sistema do agricultor (S.A.) e manejo de pragas (M.P.). 
de-pragas (M.P.).

Para a lagarta da maçã, ācaro rajado e ácaro branco apesar das värias pulverizações no tratamento sistema do produtor, nota-se pela Tabela 6 que o nümero de plantas in festadas não diferiu estatisticamente do tratamento manejo de pragas e testemunha. A explicação para isto, se deve provavelmente à eliminação dos inimigos naturais causada pelas sucessivas pulverizações no tratamento sistema do produtor con forme BLEICHER e FERRAZ (1980), o que pode ser notado pela tabela 8 e figuras 9 a 16 onde as populaçóes de coccinelitios e sirfídeos são inferiores neste tratamento diferindo estatísti camente do manejo de pragas.

Entretanto ARAUJO (1981) concluiu que a ocorrência do curuquerê reduz significativamente a incidência de lagarta da maçã na cultura algodoeira. Observa-se ainda pelas tabelas 3,4 e 5 que não houve aparecimento da lagarta ro sada, talvez devido à semeação antecipada em relação a época recomendada para a região, pois de acordo com SANTOS (1984) essa seria uma maneira de fugir das infestações tardias da praga na lavoura.

\subsection{EFEITOS NA PRODUTIVIDADE}

Os dados de produtividade de algodão em caroço e sua anălise de variância constam das Tabelas 10 e 11 e as percentagens de plantas infestadas pelas pragas nos diferen - 
tes tratamentos estão nas figuras de 2 a 8 . Nestas se observa que apesar destas infestações de pragas diferirem estatística mente, não houve efeito na produtividade entre os tratamentos manejo de pragas e sistema do produtor, o que está de acordo com as recomendações de BLEICHER e FERRAZ (1980) em relação aos níveis de dano que não causam redução na produção.

\subsection{EFEITOS NOS CUSTOS DE TRATAMENTO}

Nas tabelas 12 e 13 constam os custos totais de controle das pragas nos diferentes tratamentos e na Tabela 14 estā a comparação entre estes custos.

Nota-se que no tratamento sistema do agricultor (S.A.) foram efetuadas 9 pulverizações a um custo total de Cr\$24.226,10/ha enquanto que no manejo de pragas efetuaram se apenas 3 pulverizações mais 3 parciais em reboleiras de 50,80 e $100 \mathrm{~m}^{2}$ totalizando um custo de $\operatorname{Cr} \$ 10.164,77 / \mathrm{ha}$ o que representa uma economia de $\operatorname{Cr} \$ 14.061,33 /$ ha; portanto uma redução de $58 \%$ nos custos de controle em relação ao tratamento sistema do produtor.

\subsection{CONTROLE DO ÁCARO RAJADO-Tetranychus urticae, (Kock, 1838) EM REBOLEIRA}

A comparação entre os custos de controle do ácaro rajado em reboleira e o sistema do agricultor na área 
total constam na Tabela 15 onde observou-se uma redução de duas pulverizações na área total a um custo de $\operatorname{Cr} \$ 8.859,00 /$ ha para una, realizada em reboleiras de 50,80 e $100 \mathrm{~m}^{2}$ a um custo de apenas $\operatorname{Cr} \$ 108,67 /$ ha o que corresponde a uma diferença no custo total de controle do ácaro de $98,77 \%$.

Nota-se ainda pelas Tabelas 3,4 e 6 que apesar das pulverizações na área total, no sistema do agricultor não houve diferença estatística entre o nümero de plantas infestadas com ácaro rajado.

0 controle em reboleira permitiu maior eficiên cia do acaricida e proteção aos inimigos naturais, mantendo baixa a percentagem de plantas infestadas durante a fase crítica para a incidência de ácaro rajado até aos 90 dias e que dessa época em diante nao há diferença na produção conforme NAKANQ (1980).

\subsection{EFEITO DA SEMENTE TRATADA NO CONTROLE DO COMPLEXO TRIPES E PULGÃO Aphis gossypii Glover, 1877}

A comparaçao entre os custos de controle com o uso de semente tratada e não tratada está na Tabela 16 .

Através desta Tabela verifica-se que no tratạ mento sistema do agricultor (S.A.) foram realizadas 2 pulver zações para o controle de tripes a um custo de $\operatorname{Cr} \$ 1.974,40$ ha sendo que no tratamento manejo de pragas (M.P.) foi realizado apenas o tratamento de sementes a um custo de $\operatorname{Cr} \$ 1.250,00$ Ma; portanto uma redução de $36,68 \%$ no custo total de controle des 
ta praga.

Pela Tabela 6 observa-se que não houve diferença estatística significativa nas percentagens de plantas infestadas por tripes, enquanto que no tratamento testemunha a infestação por esta praga foi alta, diferindo estatisticamente dos tratamentos manejo de pragas (M.P.) e sistema de agricultor (S.A.), o que mostra também a eficiência das sementes tra tadas no controle de tripes.

A utilização de defensivos em puiverizições após o sstabelecimento de altas populações não é suficiente para evitar perdas significativas na produção porque o dano é ocasionado antes da detecção da praga, segundo SANTOS (1982). Observa-se pela Tabela 13 que no tratamento sistema do produtor (sementes não tratadas) foram efetuadas 2 pulverizações para tripes aos 7 e 12 dias da emergência e 2 para pulgões, aos 40 e 46 dias, enquanto que no manejo de pragas (sementes tratadas) não houve necessidade de pulverizações para ambas as pragas sendo que a primeira pulverização em subdosagem ocorreu aos 59 dias da emergência para curuquerê, conforme Tabelas 3 e 12 .

Comparando-se as Tabelas 3 e 5 e Figura 3 nota-se que o tratamento de sementes permitiu um retardamentona infestação de pulgão atê aos 45 dias. Esse esquema possibilitará o controle destes em caso de altas infestações tardias juntamente com o controle de curuquerê, que, eventualmente,pos. sa ocorrer em infestações precoces na região cm estudo. 
Dessa forma evitou-se o uso de defensivos no início do ciclo, o que permitiu maior ação dos inimigos natu rais também contra lagarta da maçã no seu período crítico (80 115 dias) conforme BLEICHER e FERRAZ (1980).

\subsection{Flutuacão da POPULACÃO de ÁCARO RAJAdO - Tetranychus urticae Koch, 1836}

A população de ảcaro rajado em função da precipitação pluvial está relatada na Tabela 17 e com estes dados foi elaborada a Figura 18, constatando-se quo há uma possível influência das chuvas nas infestações desta praga, embora o coeficiente de regressão seja de apenas 41,9\%. 0correu sensível redução das percentagens de plantas infestadas nos períodos de alta precipitação pluvial, mostrando o controle natural exercido pela chuva, possivelmente efeito de lavagem, o que está em consonância com CHIAVEGATO (1971).

4.7. EFEITO DO DESFOLHAMENTO PROVOCADO PELO CURUQUERE Alabama argillacea, (Hebner, 1818) NA PRODUTIVIDADE

Através da anālise de regressão polinomial realizada entre as produtividades e a percentagem total de desfolha acumulada no período de 33 a 112 dias da germinação e pela Figura 19 nota-se que as produtividades se ajustam a um polinômio do primeiro grau com $u \mathrm{~m}_{2}$ de $92,5 \%$.

Observa-se uma nítida influência da praga na 
.40 .

produtividade no período mencionado que correspondeu da emis são do primeiro botão floral ao aparecimento do primeiro capulho. 


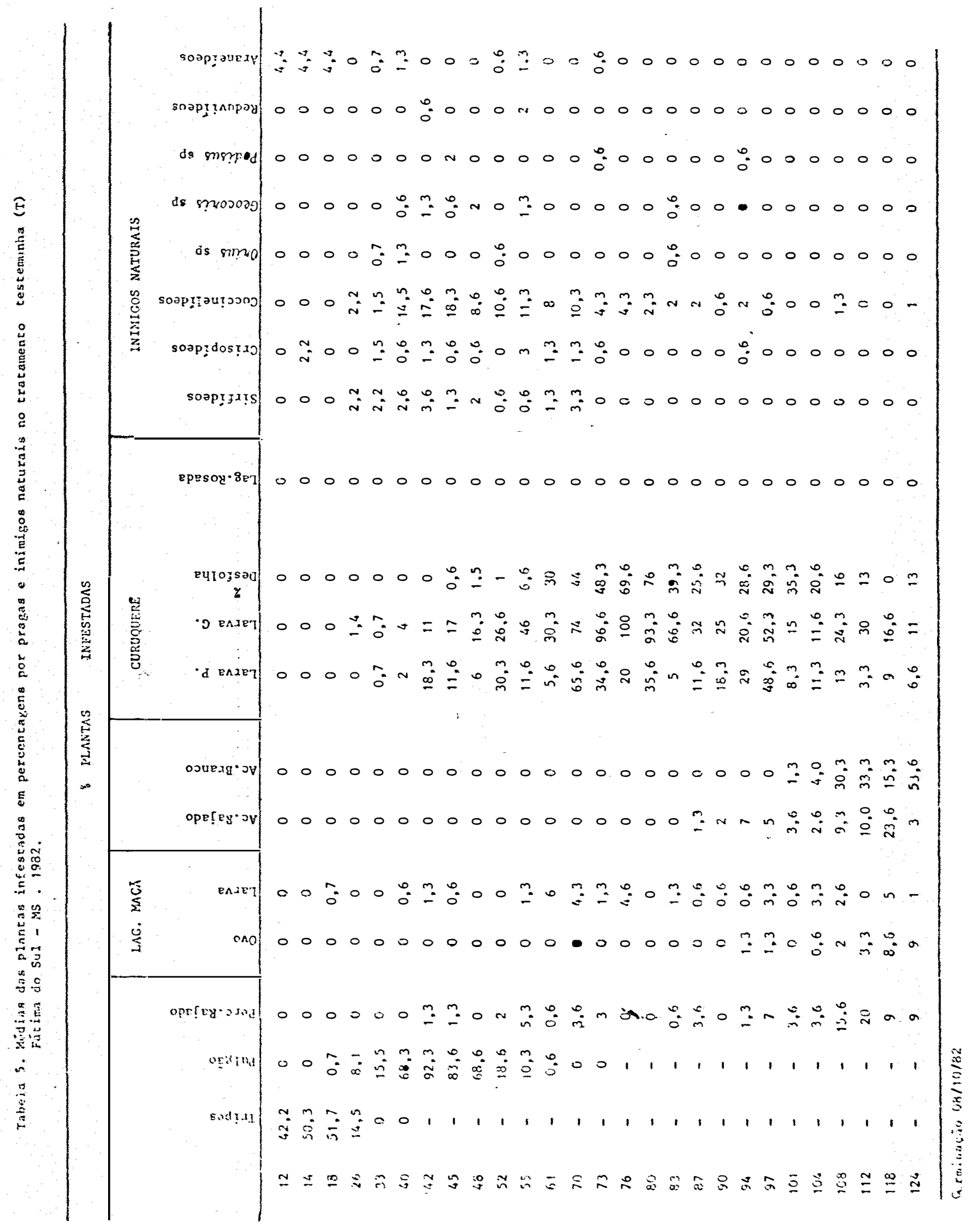




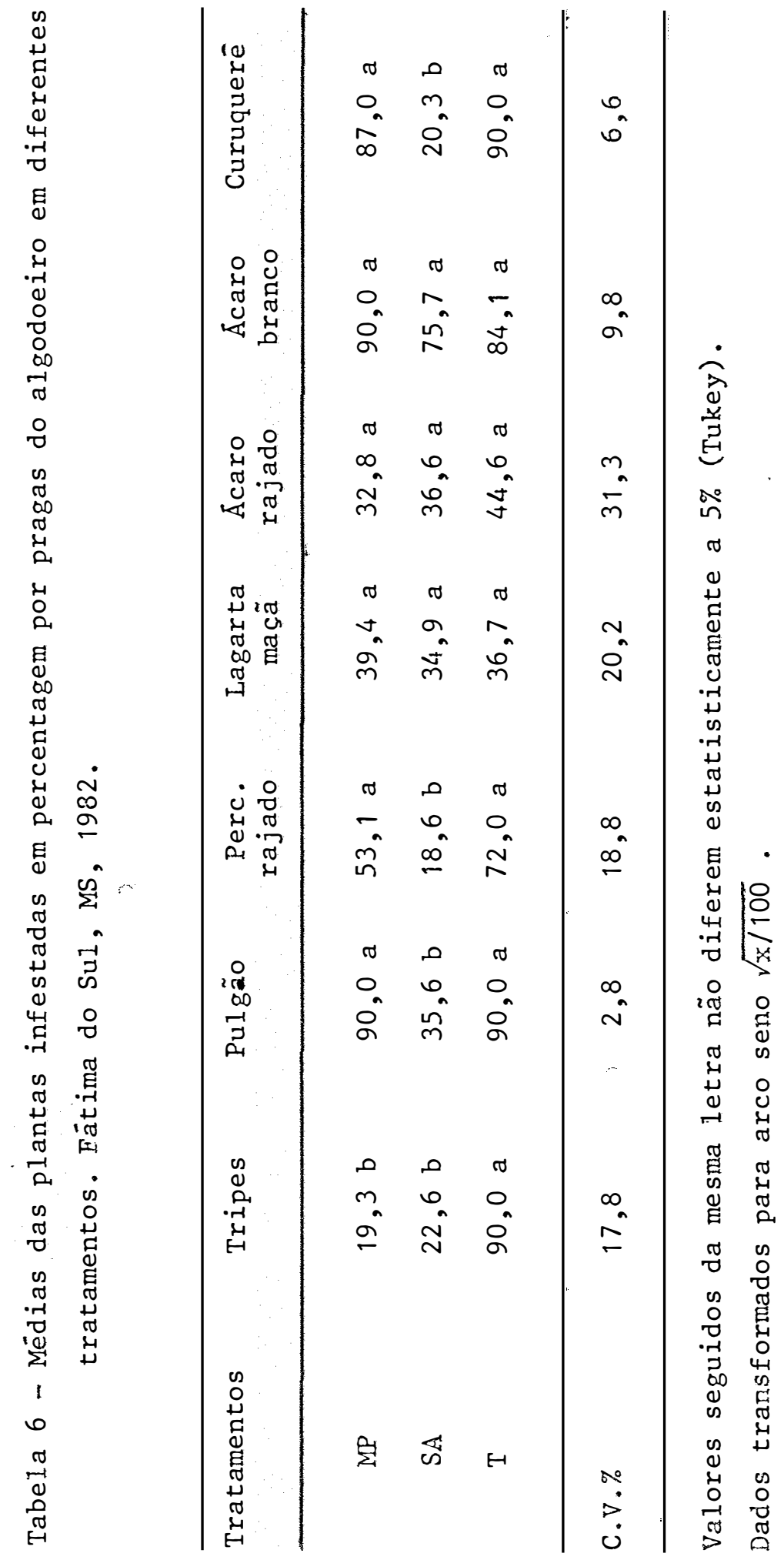




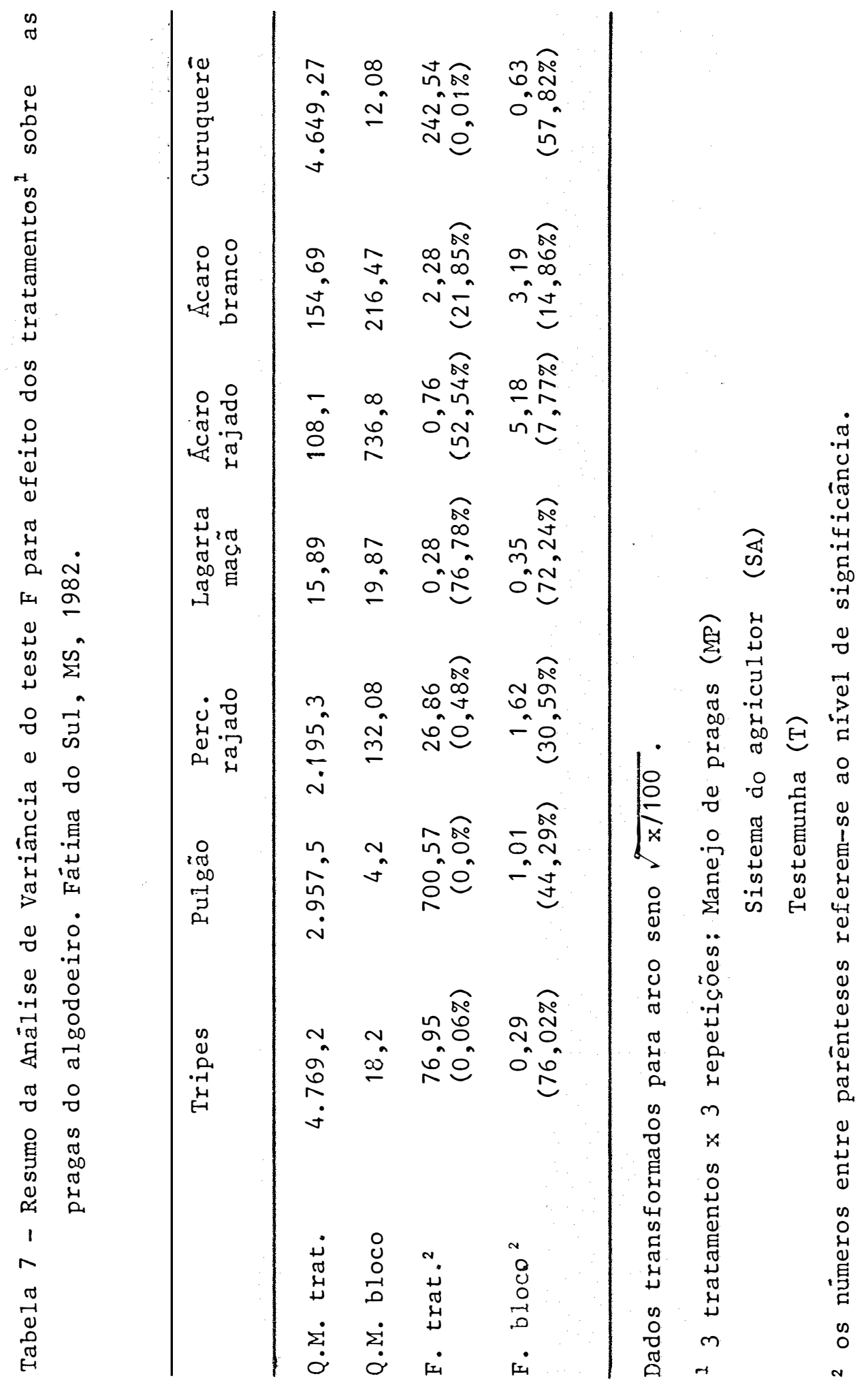


.46

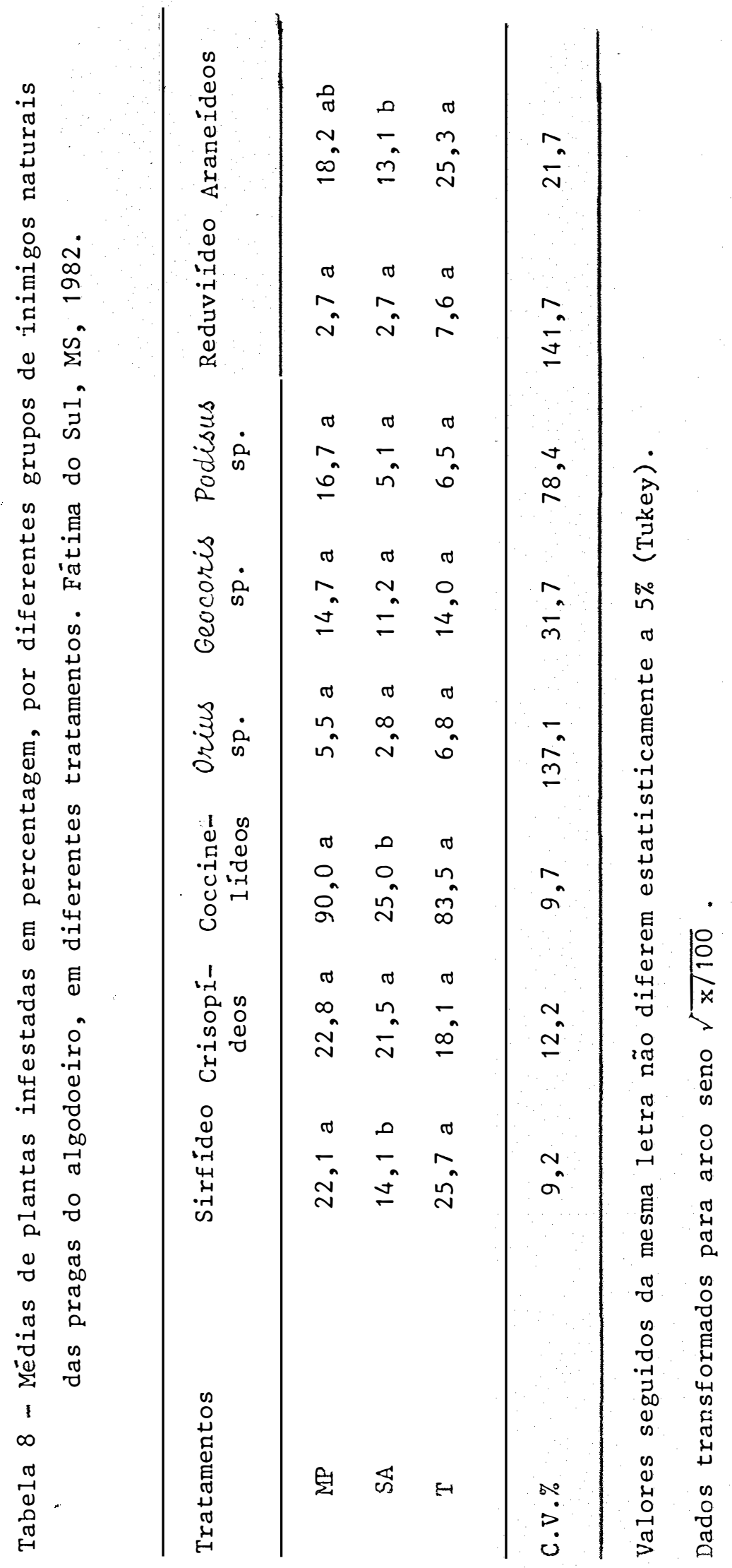




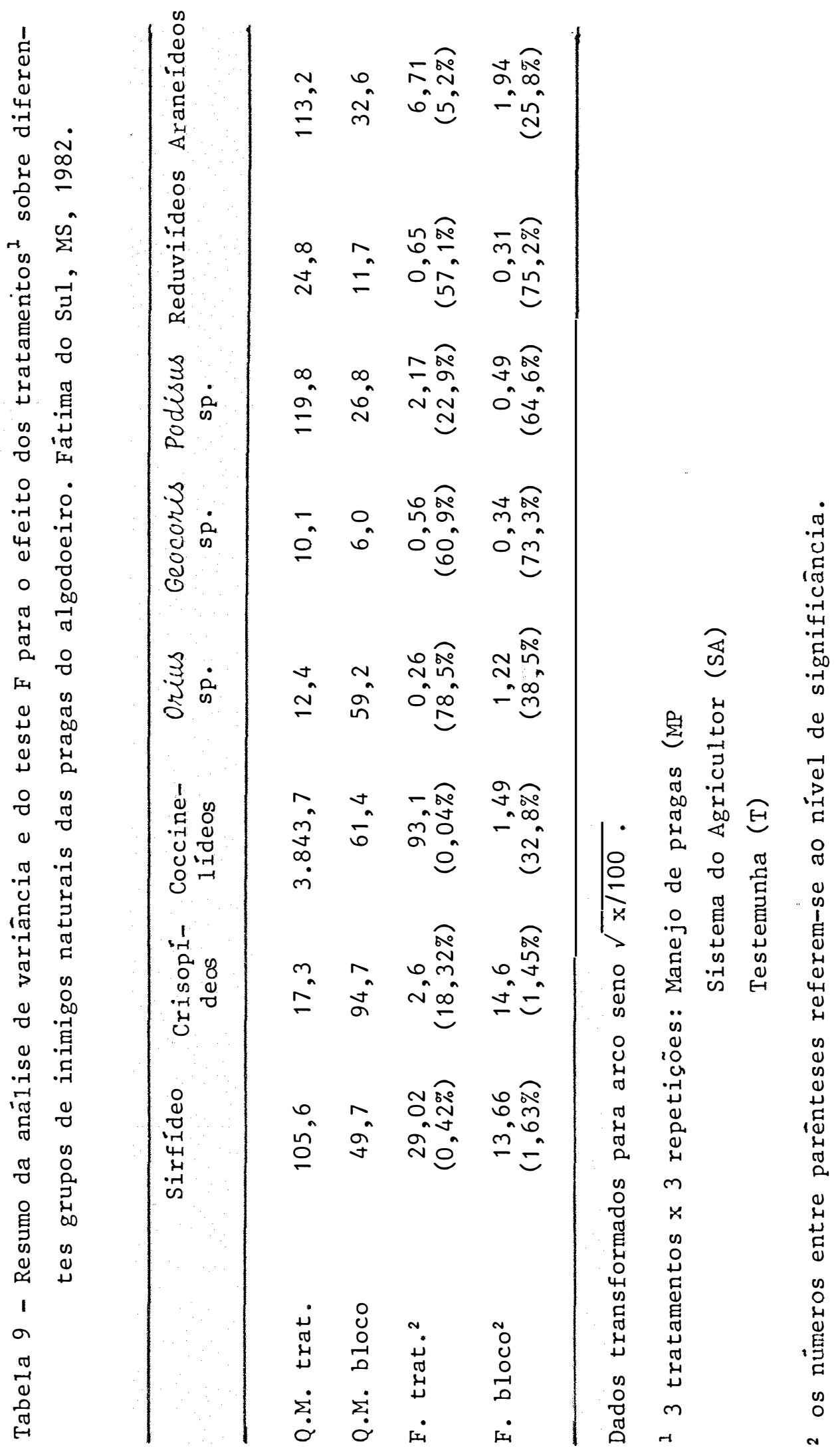


Tabela 10 - Produtividade média de algodão em caroço em kg/ha do cultivar IAC-17, submetido a diferentes tratamentos. Fátima do Sul, MS, 1982.

\begin{tabular}{ccccc} 
Tratamentos & \multicolumn{3}{c}{ Repetições } & \multirow{2}{*}{ Nédias } \\
\cline { 2 - 4 } & 1 & 2 & 3 & \\
\cline { 2 - 5 } MP & $2.170,38$ & $2.090,00$ & $2.118,74$ & $2.126,37 \mathrm{a}$ \\
SA & $2.278,75$ & $2.022,11$ & $2.160,65$ & $2.153,84 \mathrm{a}$ \\
$\mathrm{T}$ & $1.050,00$ & $1.113,19$ & $1.021,10$ & $1.061,43 \mathrm{~b}$
\end{tabular}

Médias seguidas de mesma letra não diferem entre si pelo teste de Tukey, ao nivel de $5 \%$ de probabilidade.

Tabela 11 - Resumo da Anālise de Variância para produção de algodão em ca roço, em t/ha da cultivar IAC-17, submetida a diferentes tratamentos.

\begin{tabular}{|c|c|c|c|c|}
\hline \multirow[t]{2}{*}{ Causa da Variação } & \multicolumn{4}{|c|}{ Anälise de Variância } \\
\hline & G.L. & S.Q. & Q.M. & $\mathrm{F}$ \\
\hline Blocos & 2 & 0,013340 & 0,006670 & $0,97 \mathrm{~ns}$ \\
\hline Tratamentos & 2 & 2,328210 & 1,164100 & $169,85 * *$ \\
\hline Resíduo & 4 & 0,0027414 & 0,006854 & \\
\hline Total & 8 & & & \\
\hline
\end{tabular}


.49.

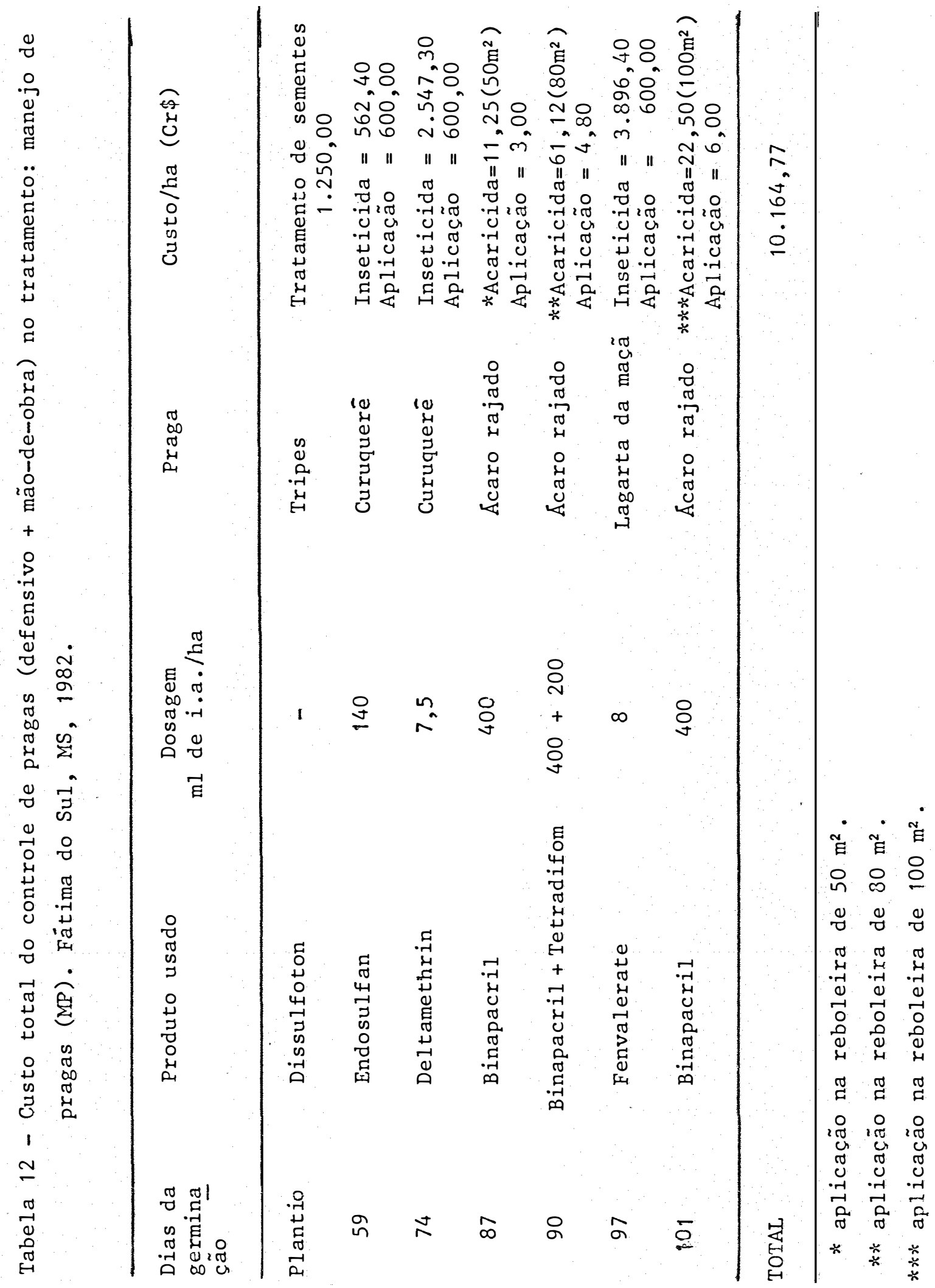




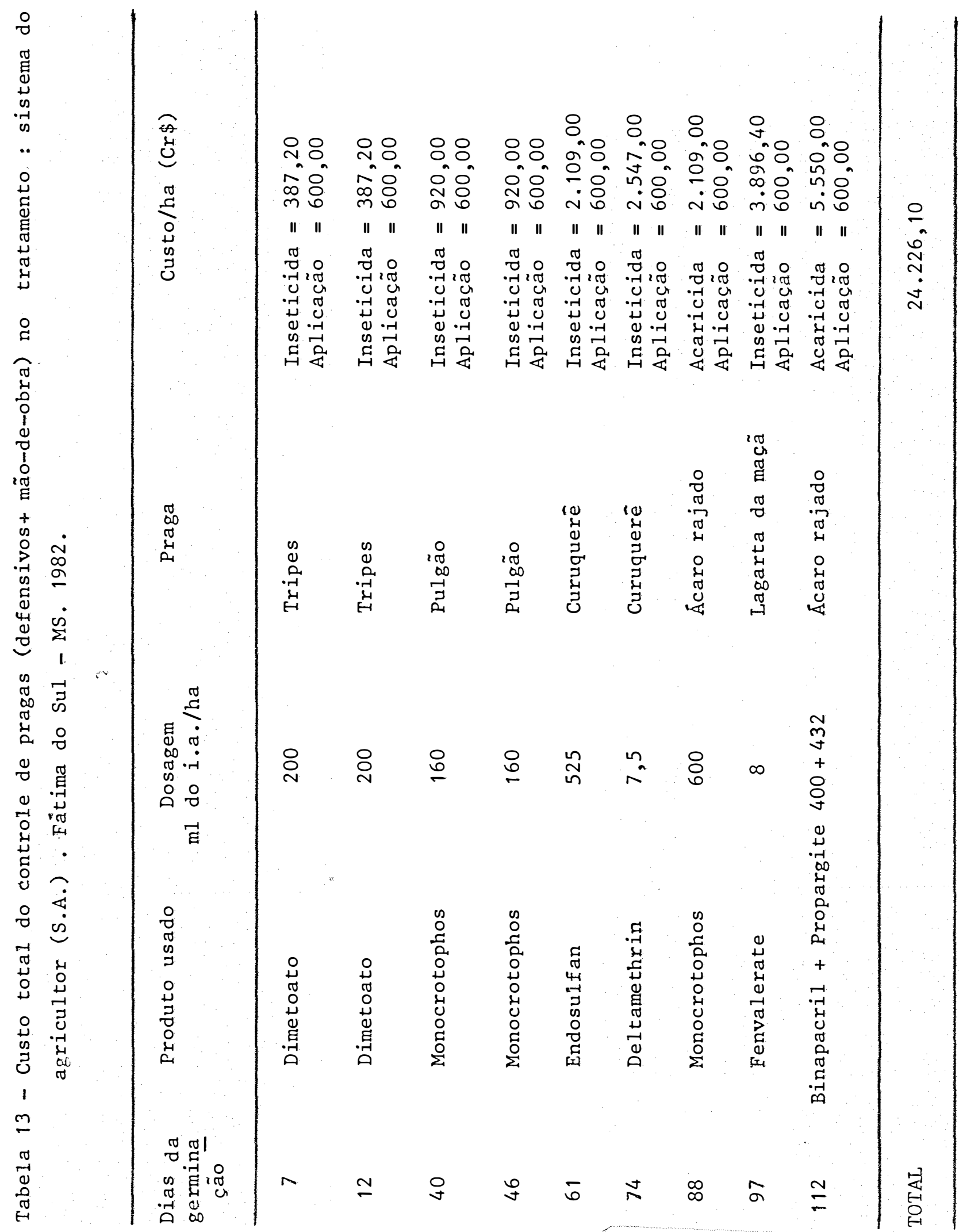




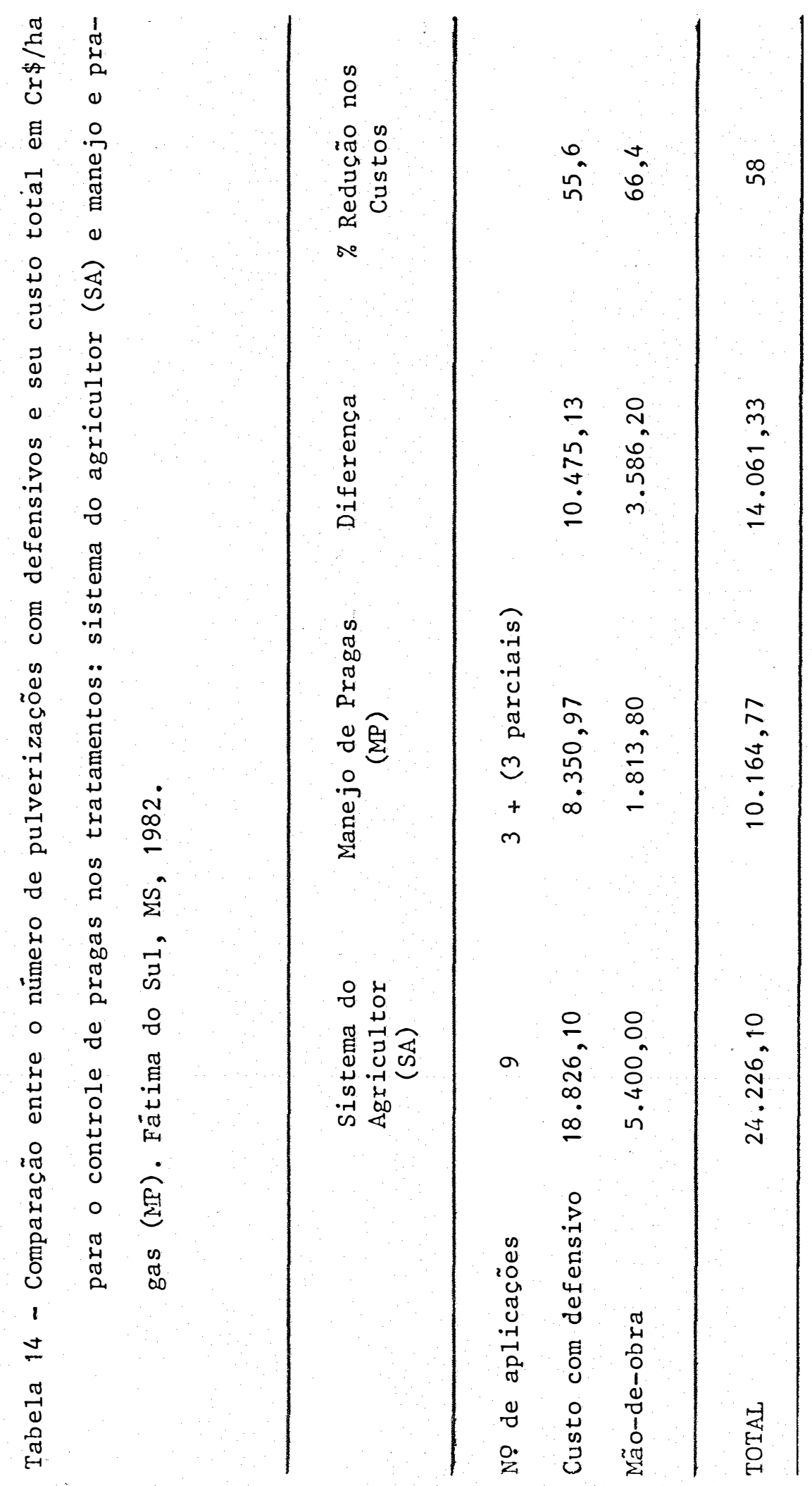




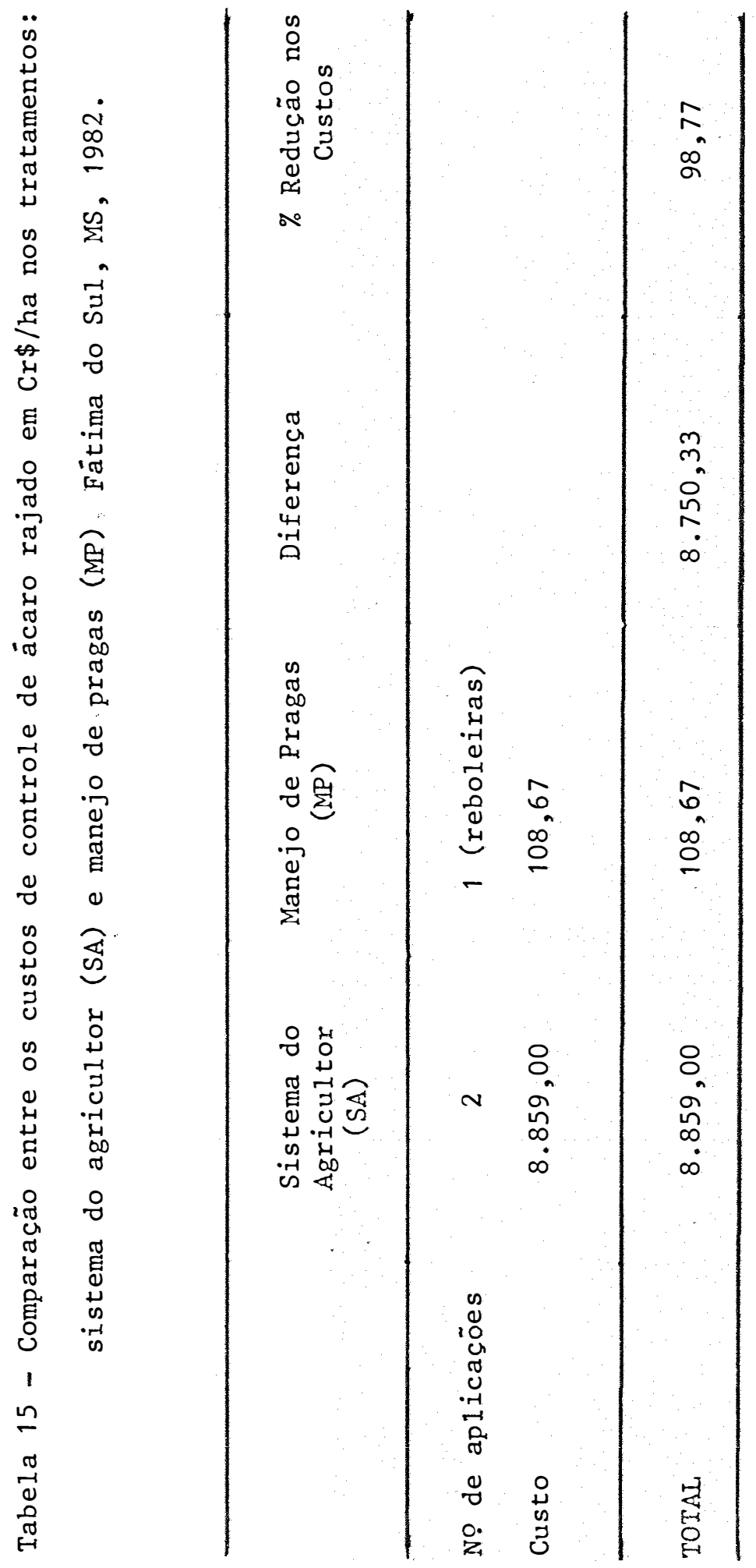




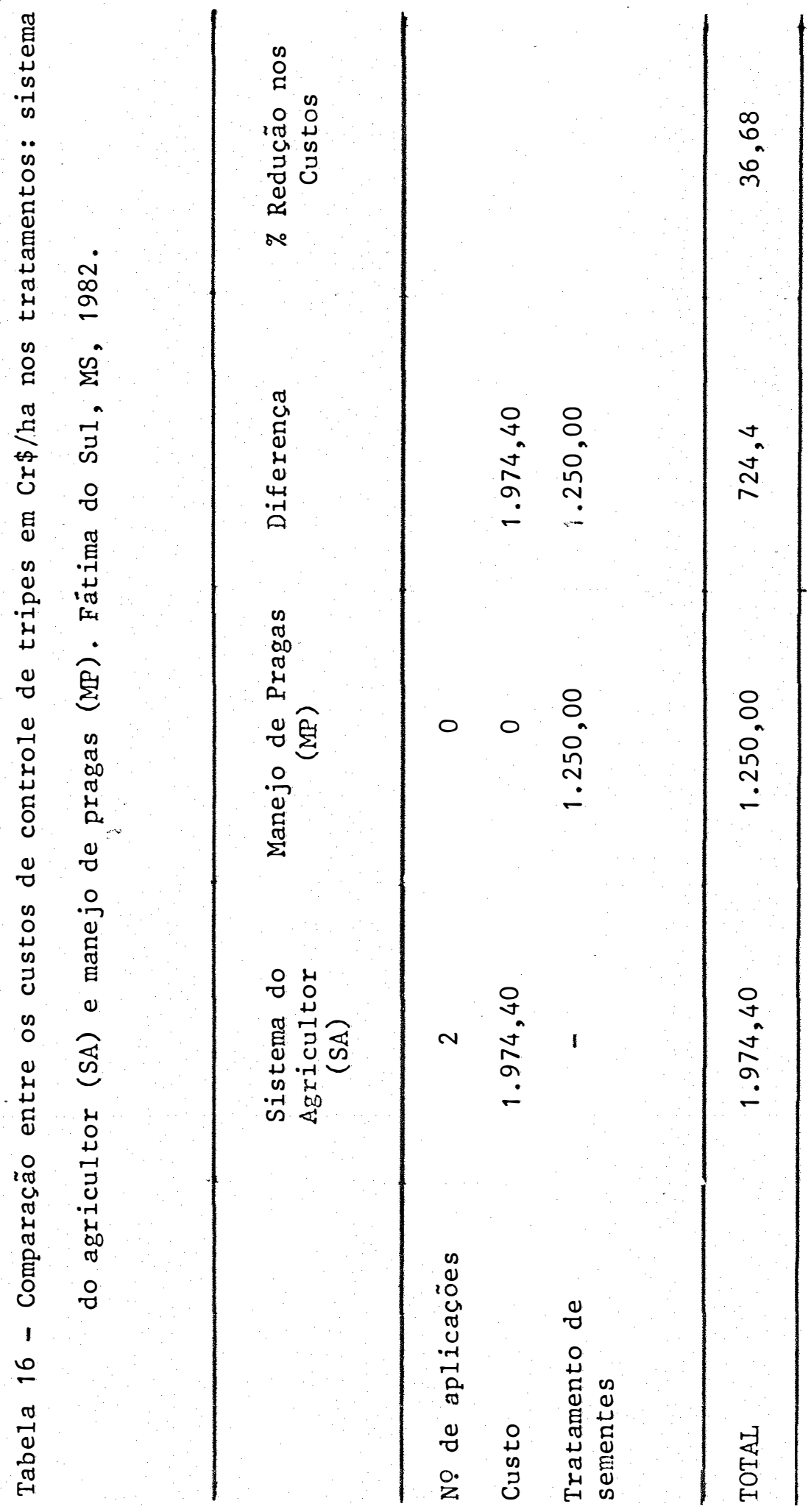


Tabela 17 - Médias das percentagens de plantas infestadas por Tetranychus urticae (Koch, 1836) durante o ciclo da cultura, com registro de precipitação pluvial no tratamento testemunha (T). Fätima do $\mathrm{Sul}, \mathrm{MS}, 1982$,

\begin{tabular}{ccc}
\hline Dias da germinação & Precipitação (mm) & Ácaros \\
\hline $83-87$ & 5,1 & 1,3 \\
$87-90$ & 0 & 2,0 \\
$90-94$ & 1,6 & 7,0 \\
$94-97$ & 3,6 & 5,0 \\
$97-101$ & 12,9 & 3,6 \\
$101-104$ & 24,3 & 2,6 \\
$104-108$ & 0 & 9,3 \\
$108-112$ & 31,8 & 10,0 \\
$112-118$ & 49,5 & 5,0 \\
$118-124$ & 2,4 & 3,0 \\
\hline
\end{tabular}




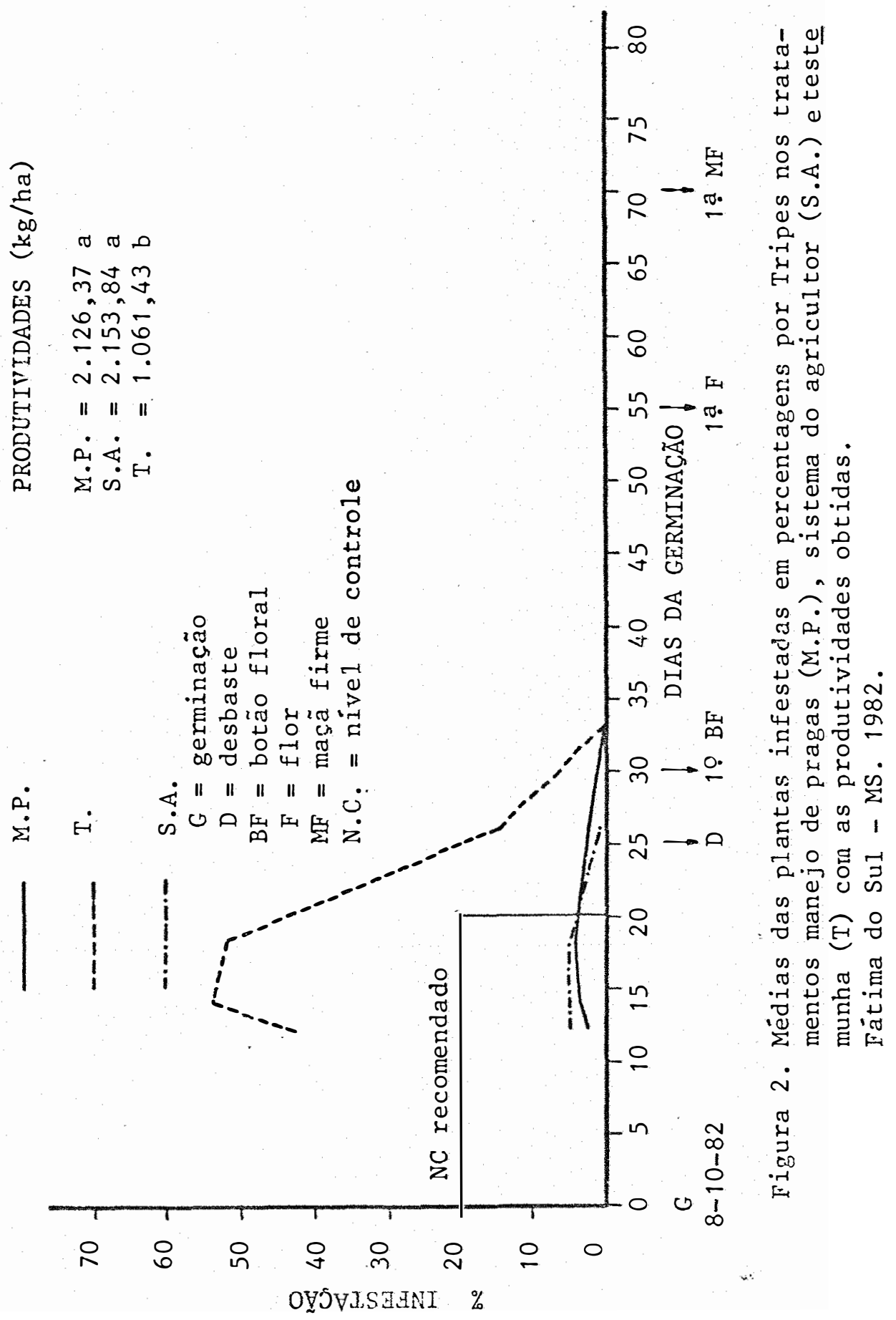




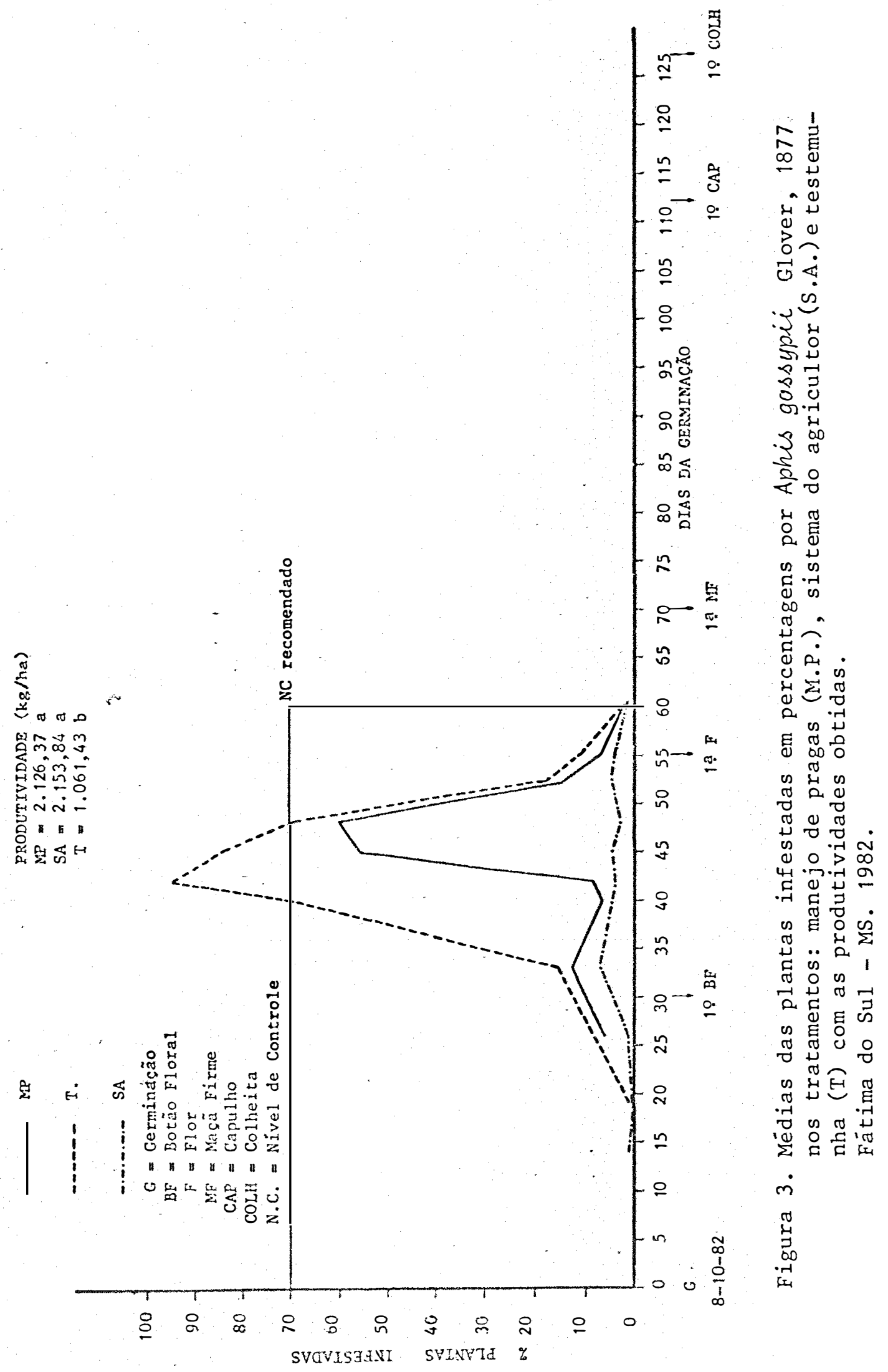




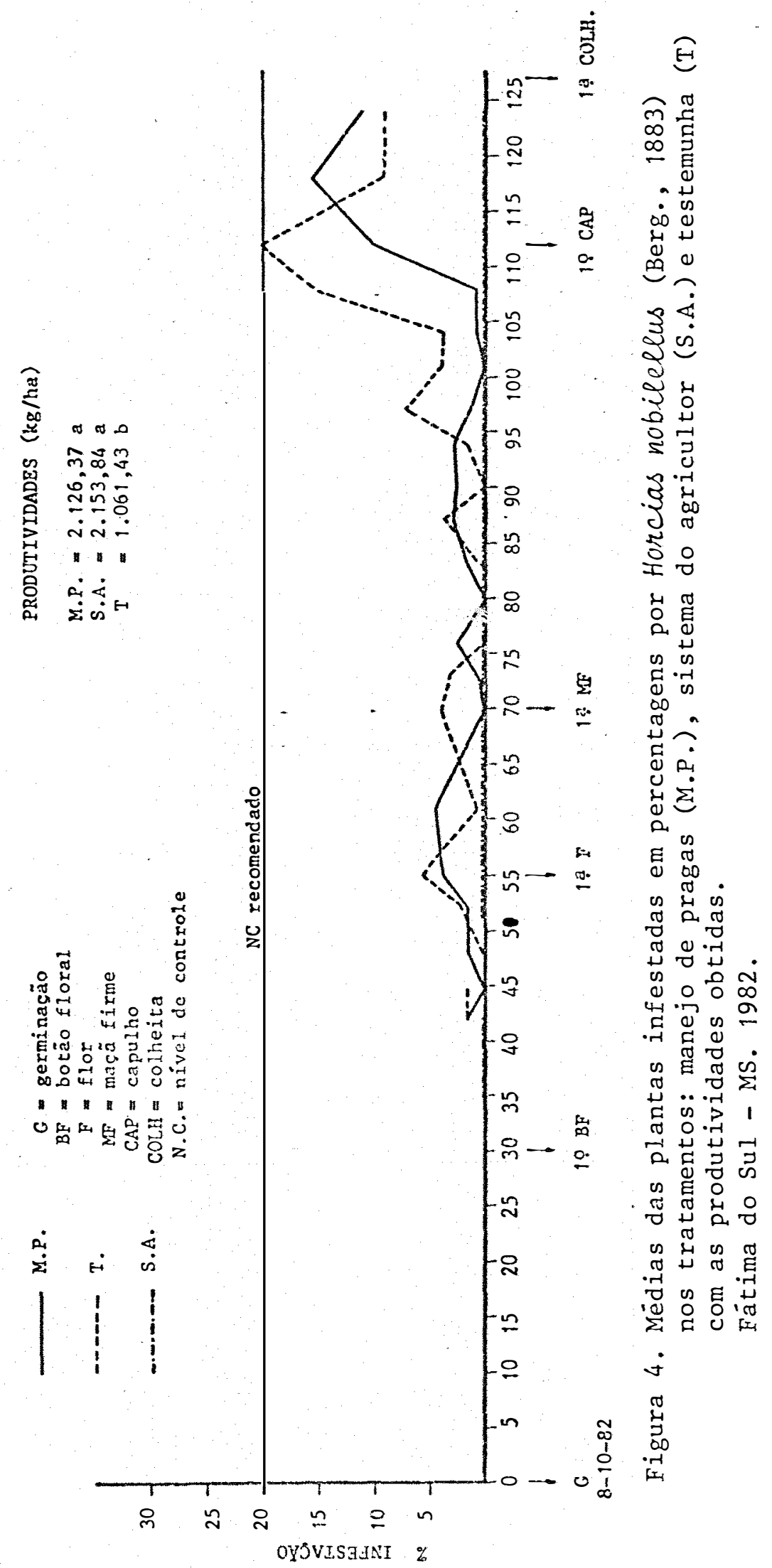



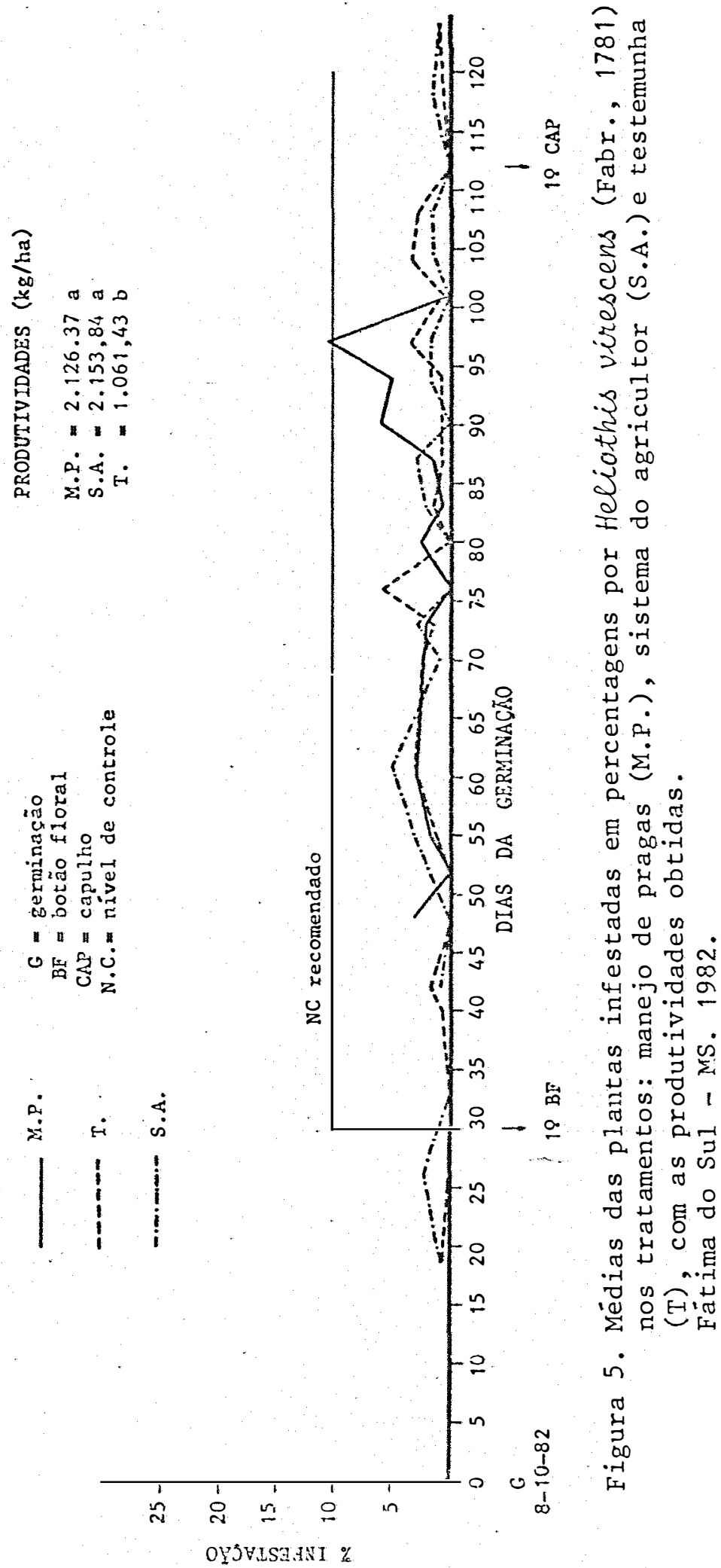


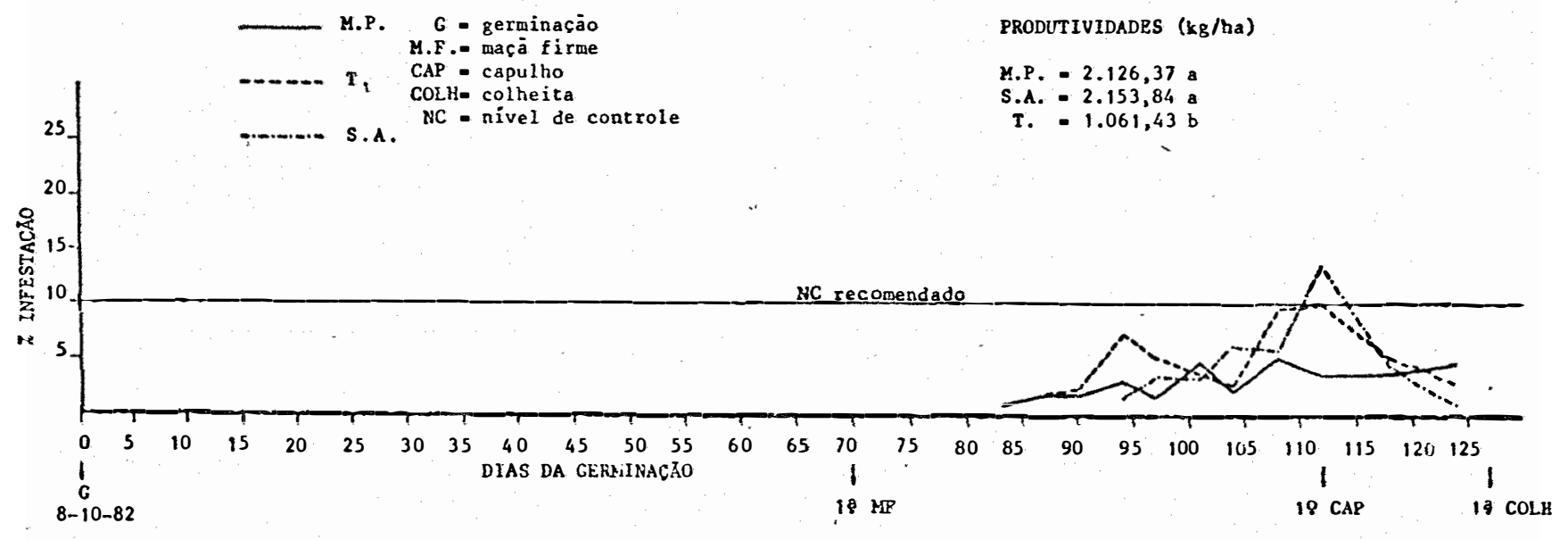

Figura 6. Médias das plantas infestadas em percentagens por Tetranychus urticae (Koch, 1836) nos tratamentos: manejo de pragas (M.P.) sistema do agricultor (S.A.)e testemunha (T) com as produtividades obtidas.

Fätima do Sul - MS. 1982. 


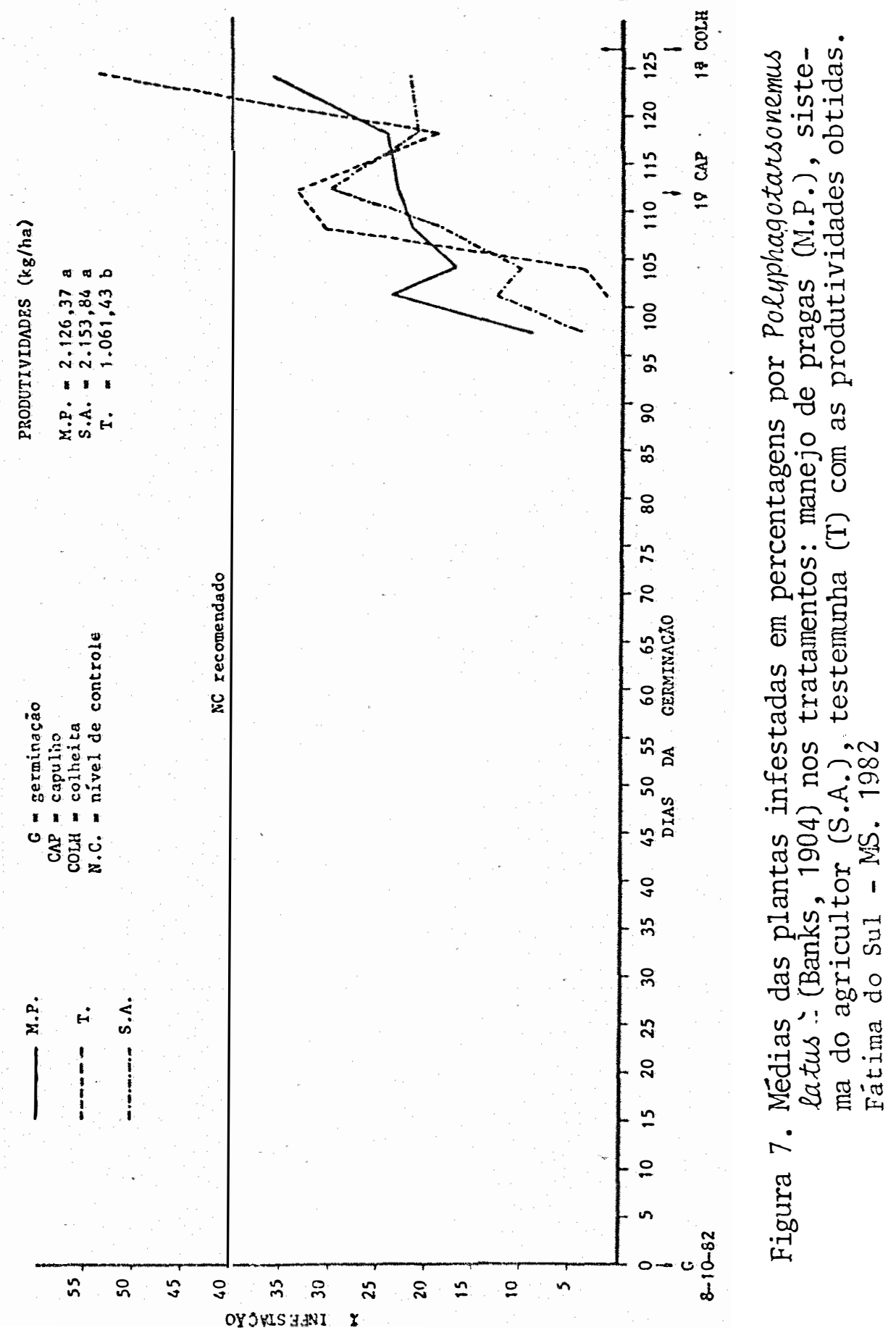




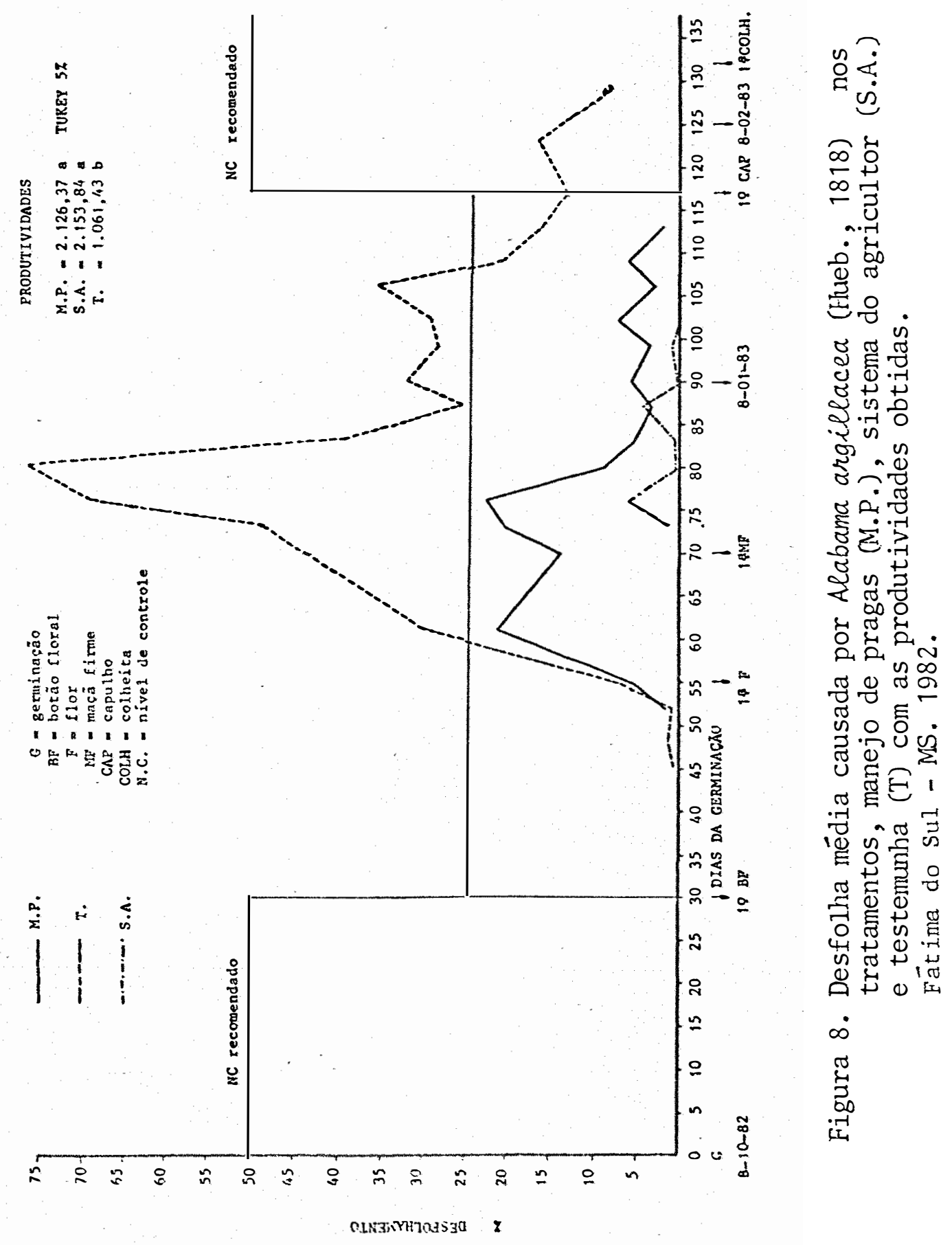




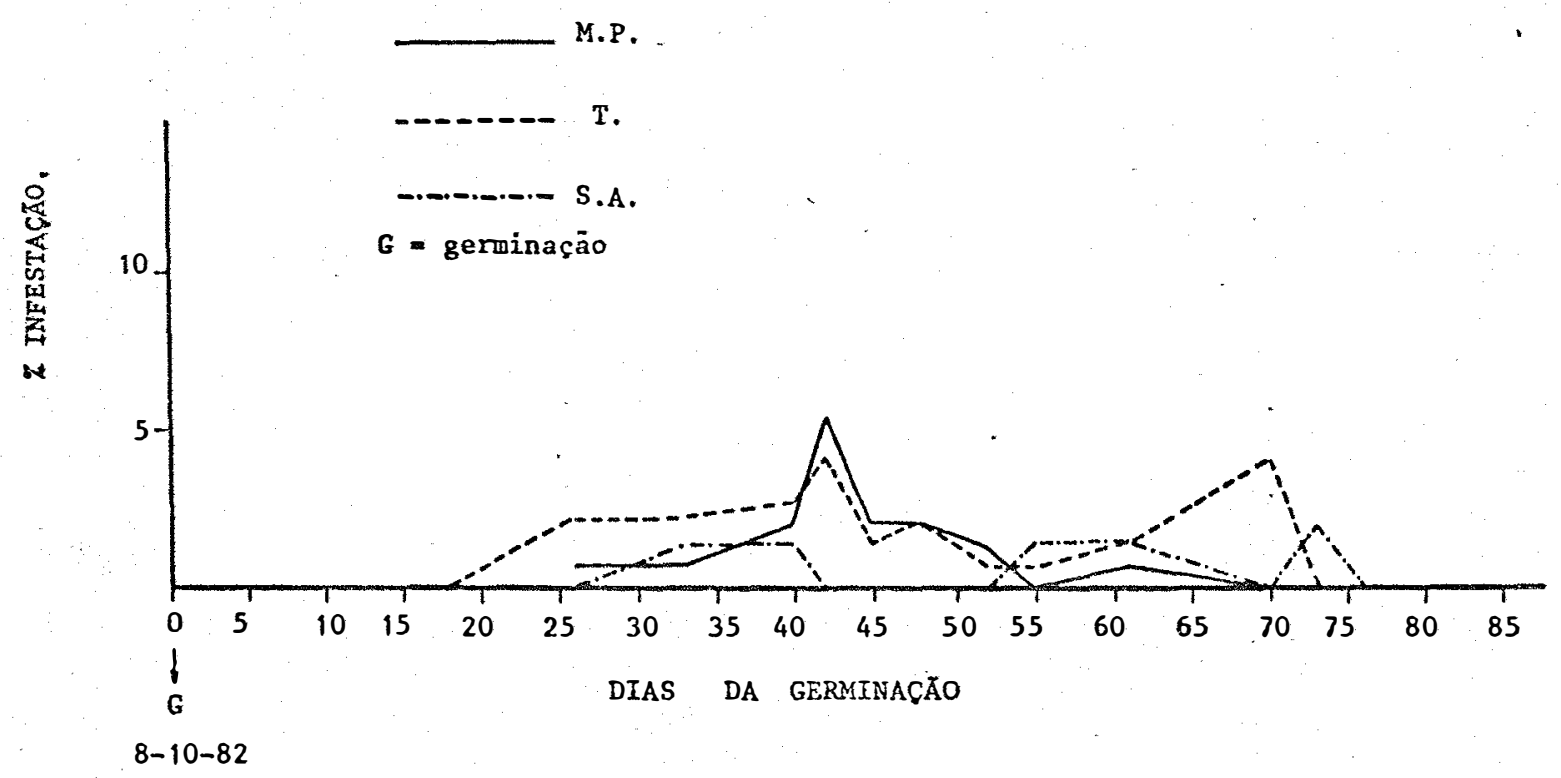

Figura 9. Médias das plantas ( $(\%)$ com presença de sírfideos nos tratamentos: manejo de pragas (M.P.) sistema do agri cultor (S.A.) e testemunha (T). Fätima do Sul - MS. 1982. 


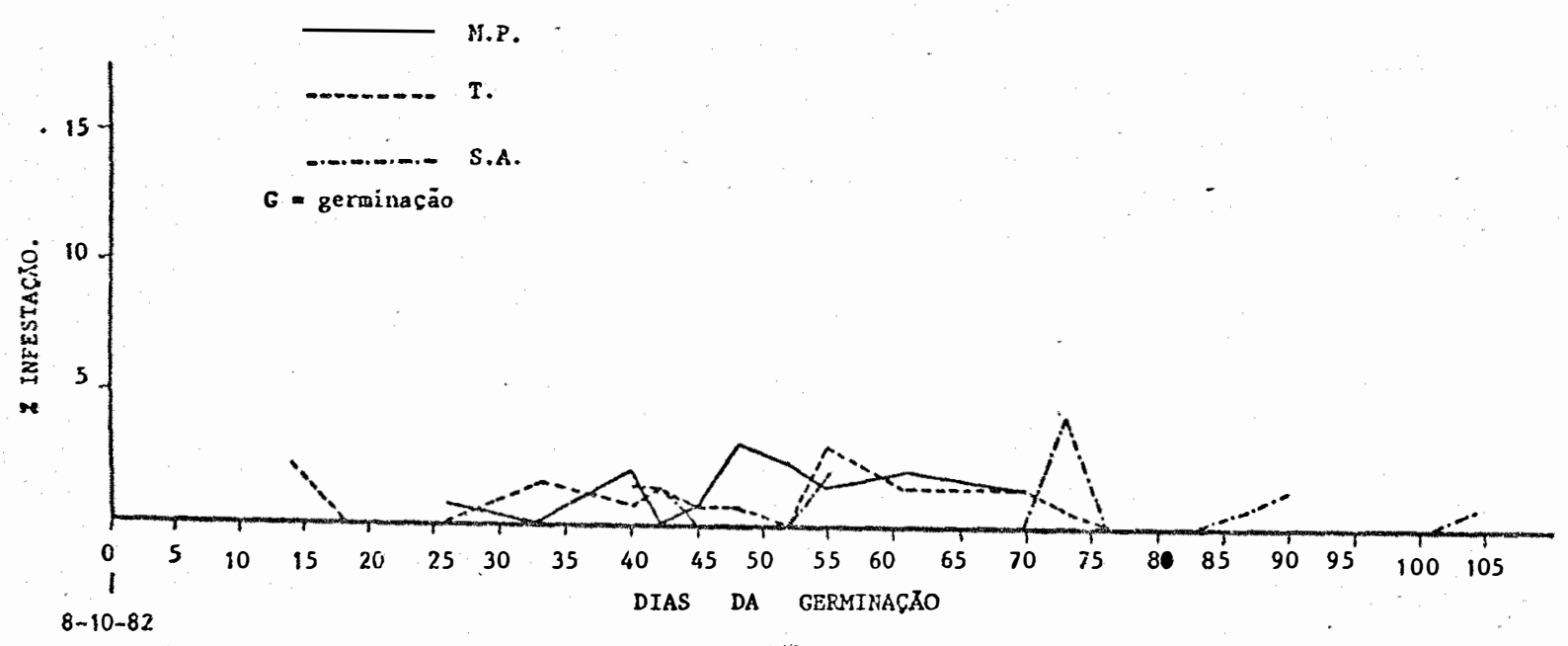

Figura 10. Médias das plantas ( $(\%)$ com presença de crisopídeos nos tratamentos: manejo de pragas (M.P.), sistema do agricultor (S.A.) e testemunha (T).

Fátima do Sul - MS., 1982. 


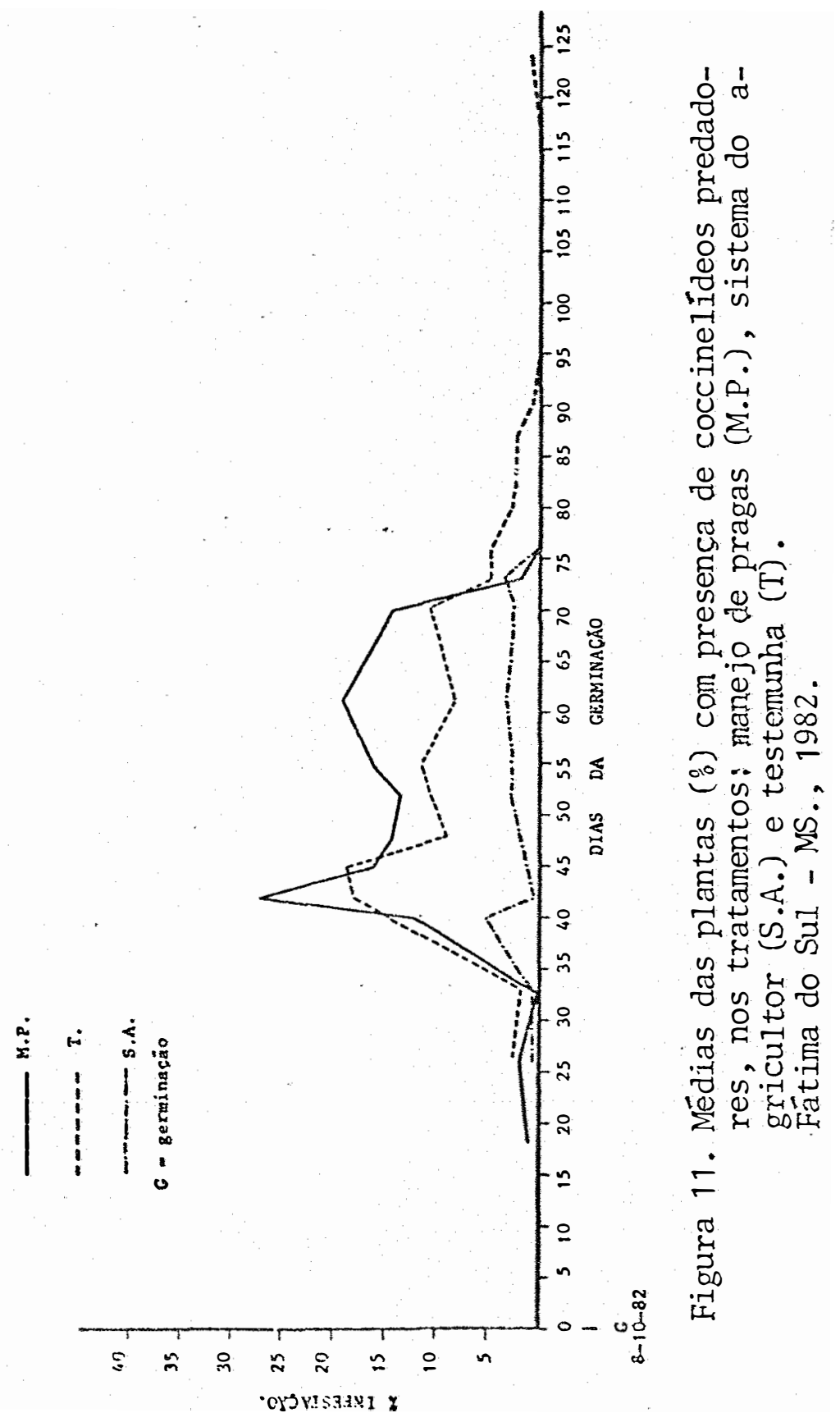




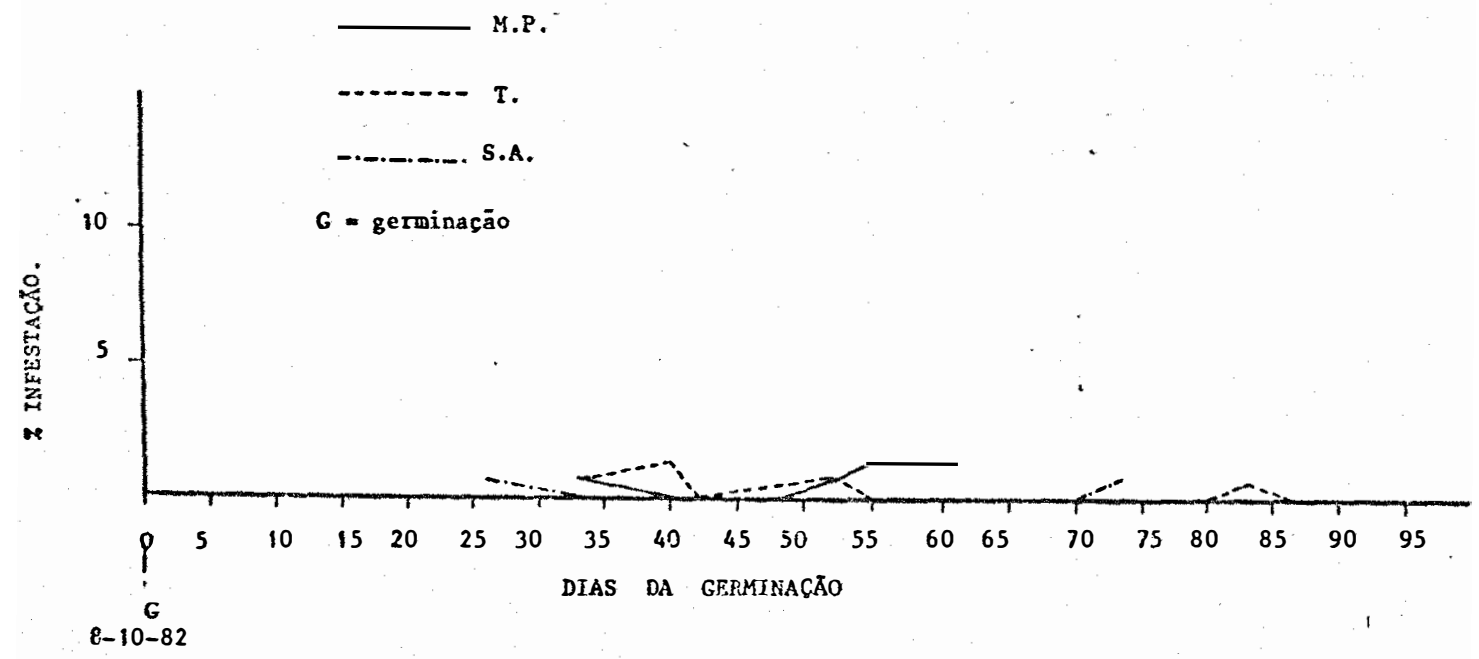

Figura 12. Médias das plantas ( $\left.\frac{\circ}{0}\right)$ com presença de Orius sp. nos tratamentos: manejo de pragas (M.P.), sistema do agricultor (S.A.) e testemunha (T.). Fätima do Sul - MS., 1982. 


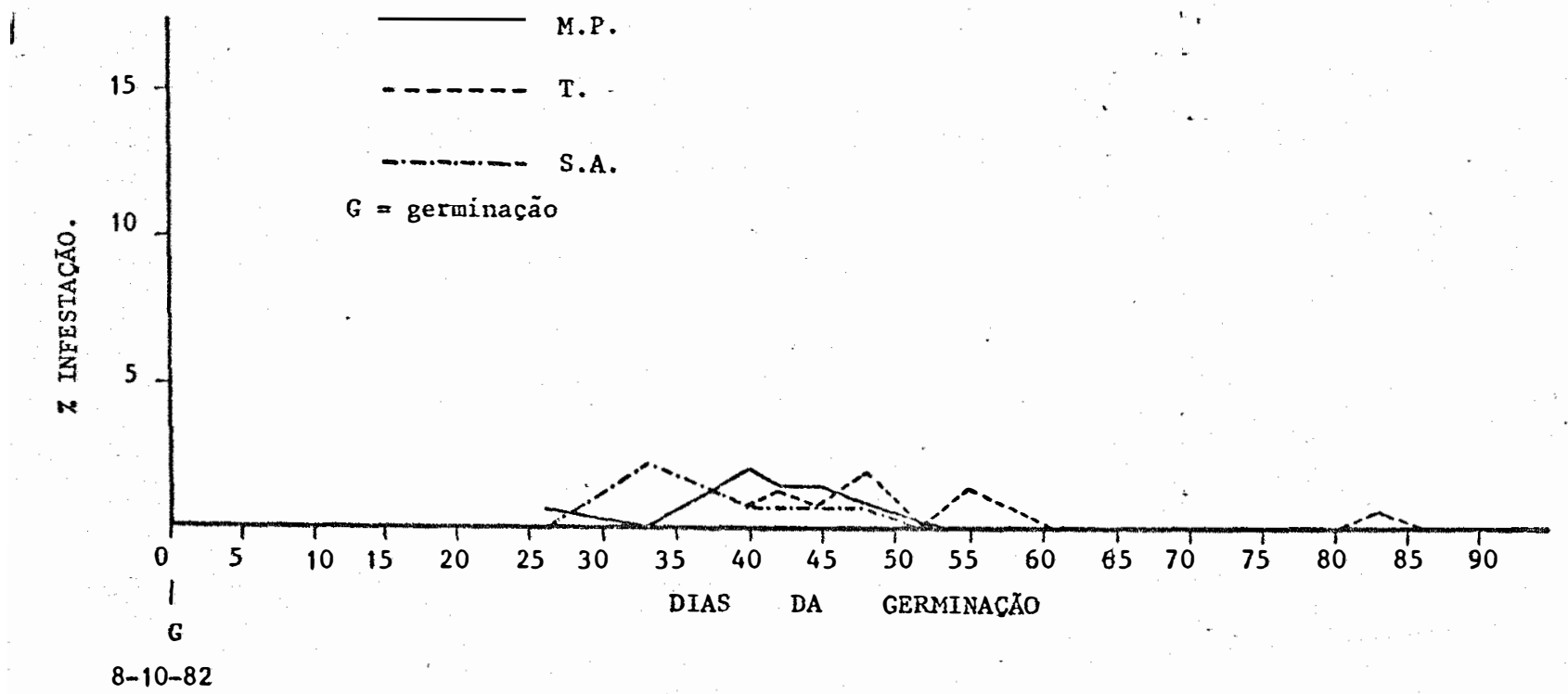

Figura 13. Mêdias das plantas ( $\left(\frac{0}{0}\right)$ com presença de Geocoris sp., nos tratamentos: manejo de pragas (M.P.), sistema do agricultor (S.A.) e testemunha (T).

Fâtima do Sul - MS., 1982. 


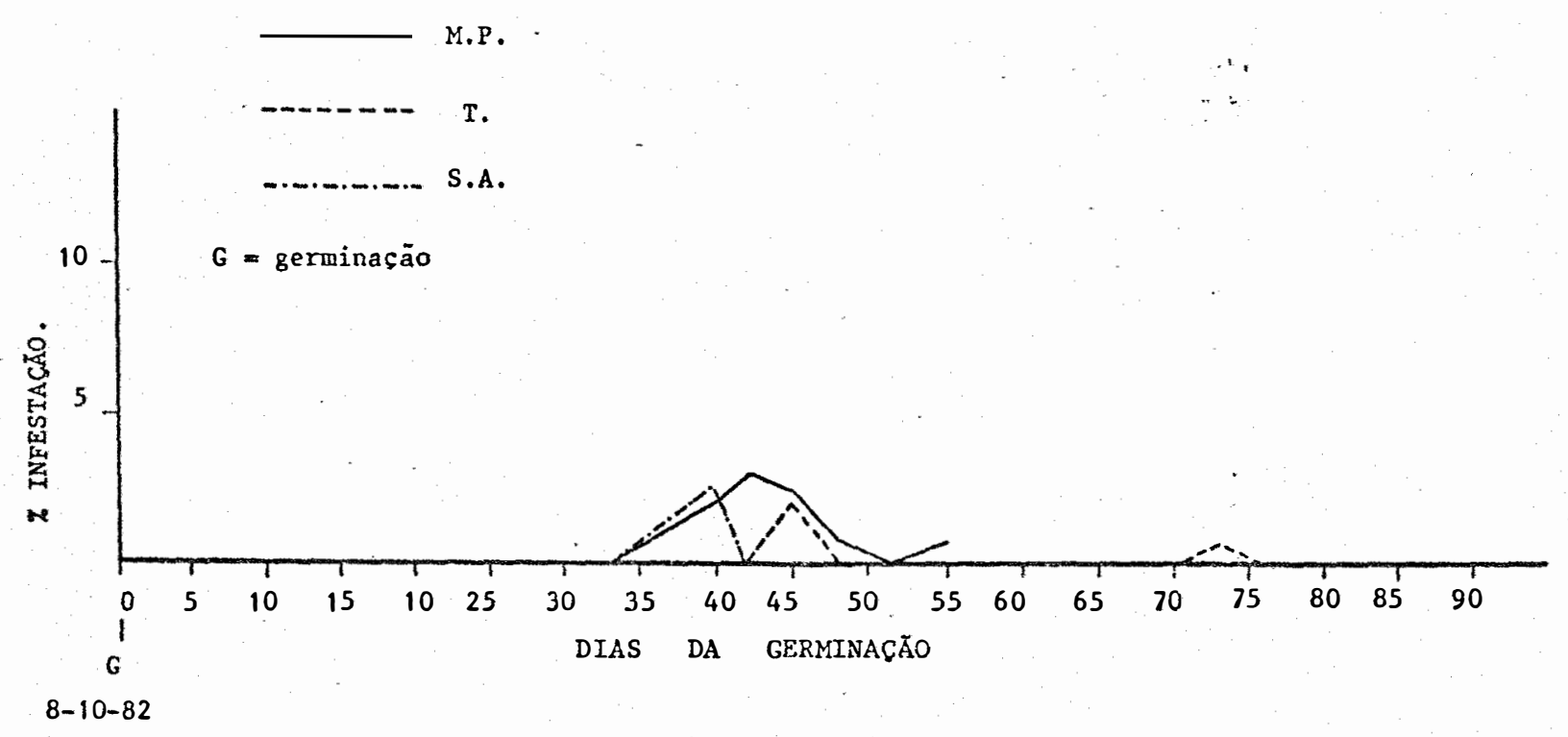

Figura 14. Médias das plantas $\left(\frac{0}{0}\right)$ com presença de Podisus sp., nos tratamentos: menejo de pragas (M.P.), sistema do agricultor (S.A.) e testemmina (T). Fätima do Sul - MS., 1982. 


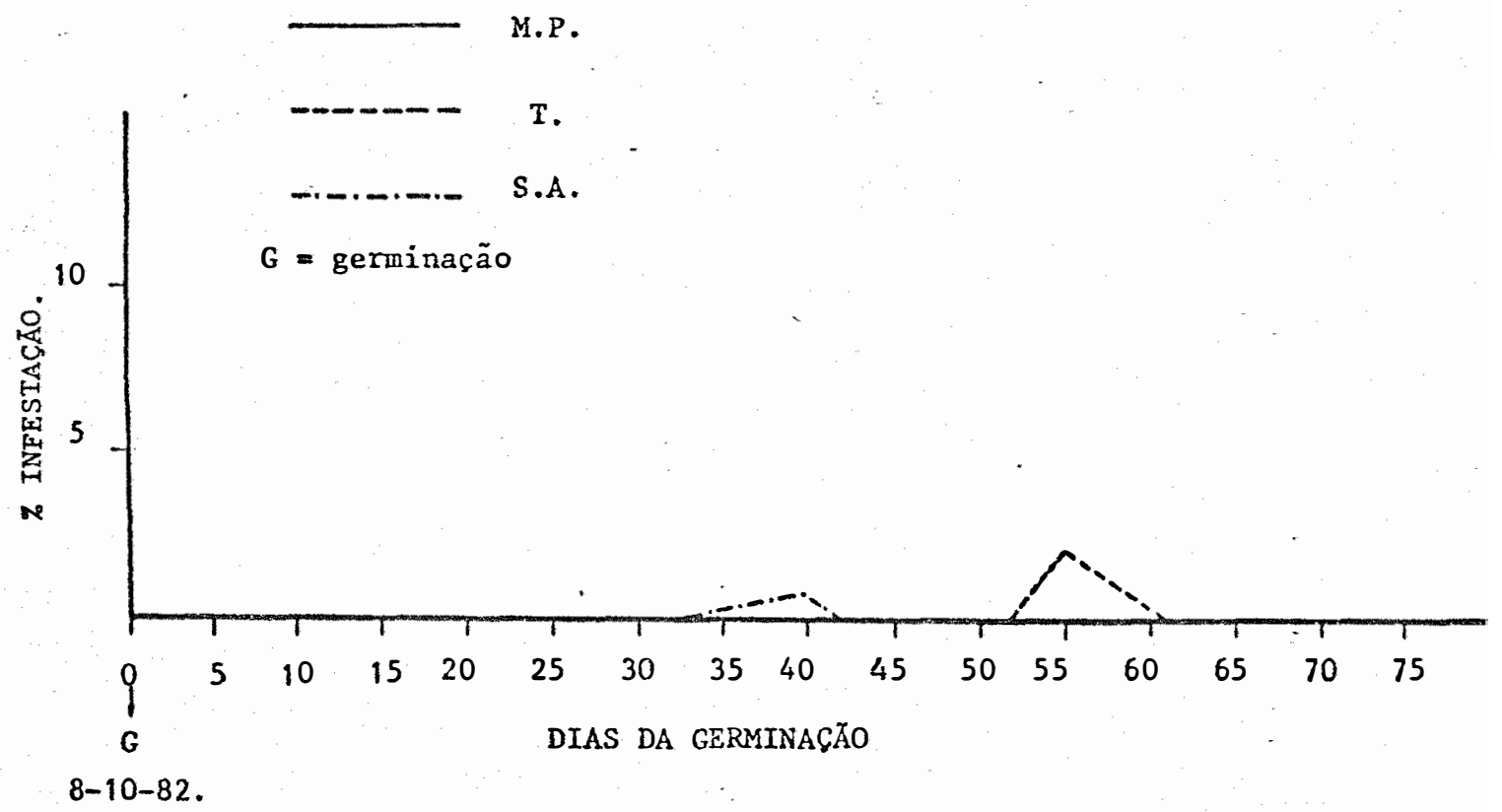

Figura 15. Mẻdias das plantas ( $\%$ ) com presença reduviídeos nos tratamentos manejo de pragas (M.P.), sistema do agricultor (S.A.) e testemunha (T). Fätima do Sul - MS., 1982. 


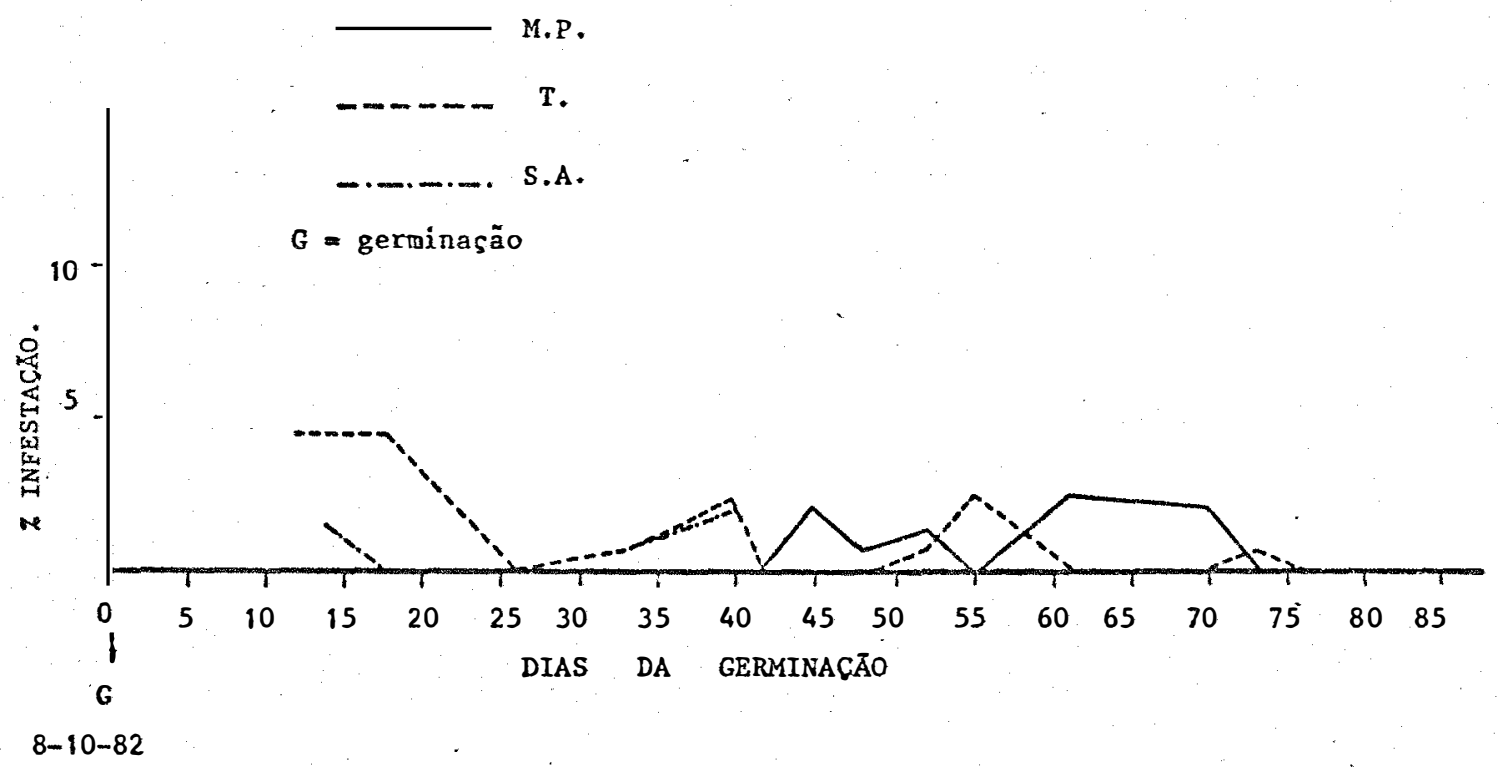

Figura 16. Médias das plantas $\left(\frac{0}{0}\right)$ com presença de araneídeos nos tratanentos: manejo de pragas (M.P.), sistema do agricultor (S.A.) e testemunha (T). Fâtima do Sul - MS., 1982. 


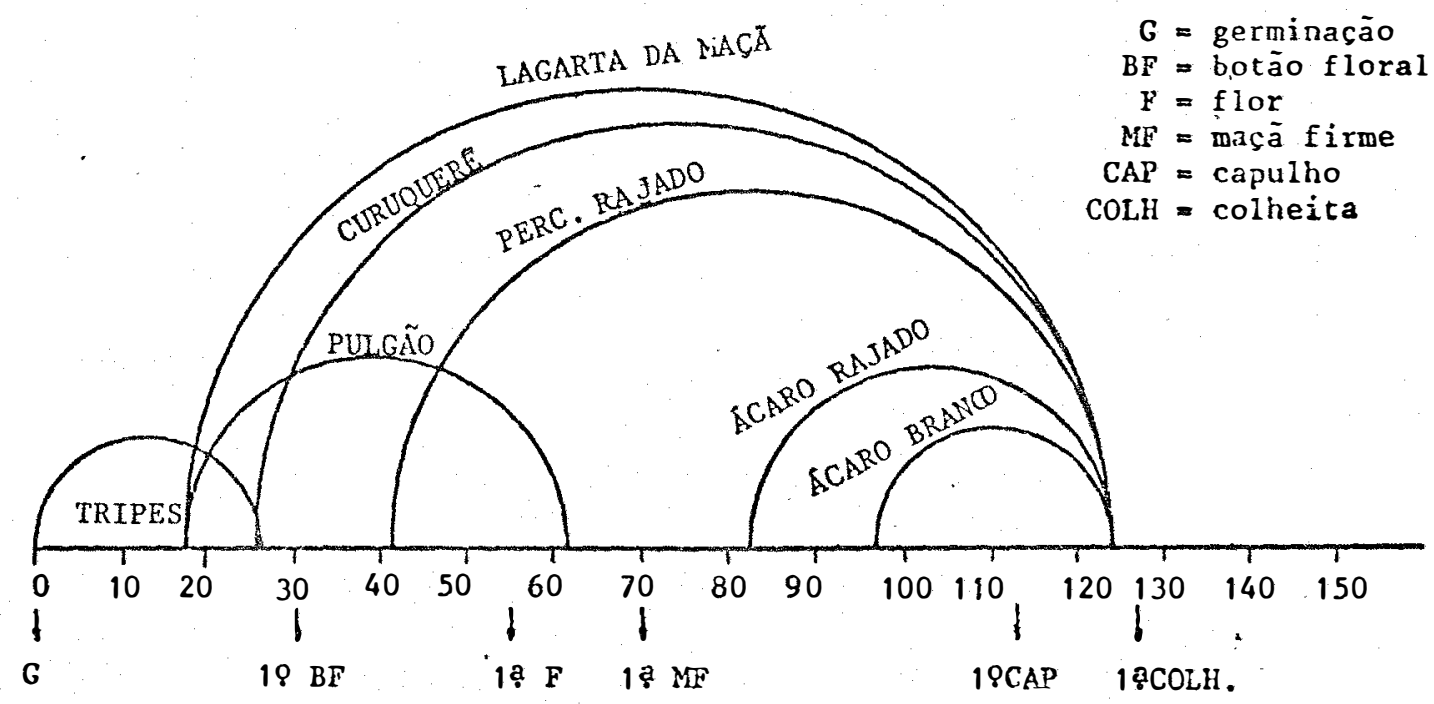

Figura 17. Fenologia e ocorrência de pragas do algodoeiro no tratamento testemunha. Fátima do Sul - MS. 1982. 


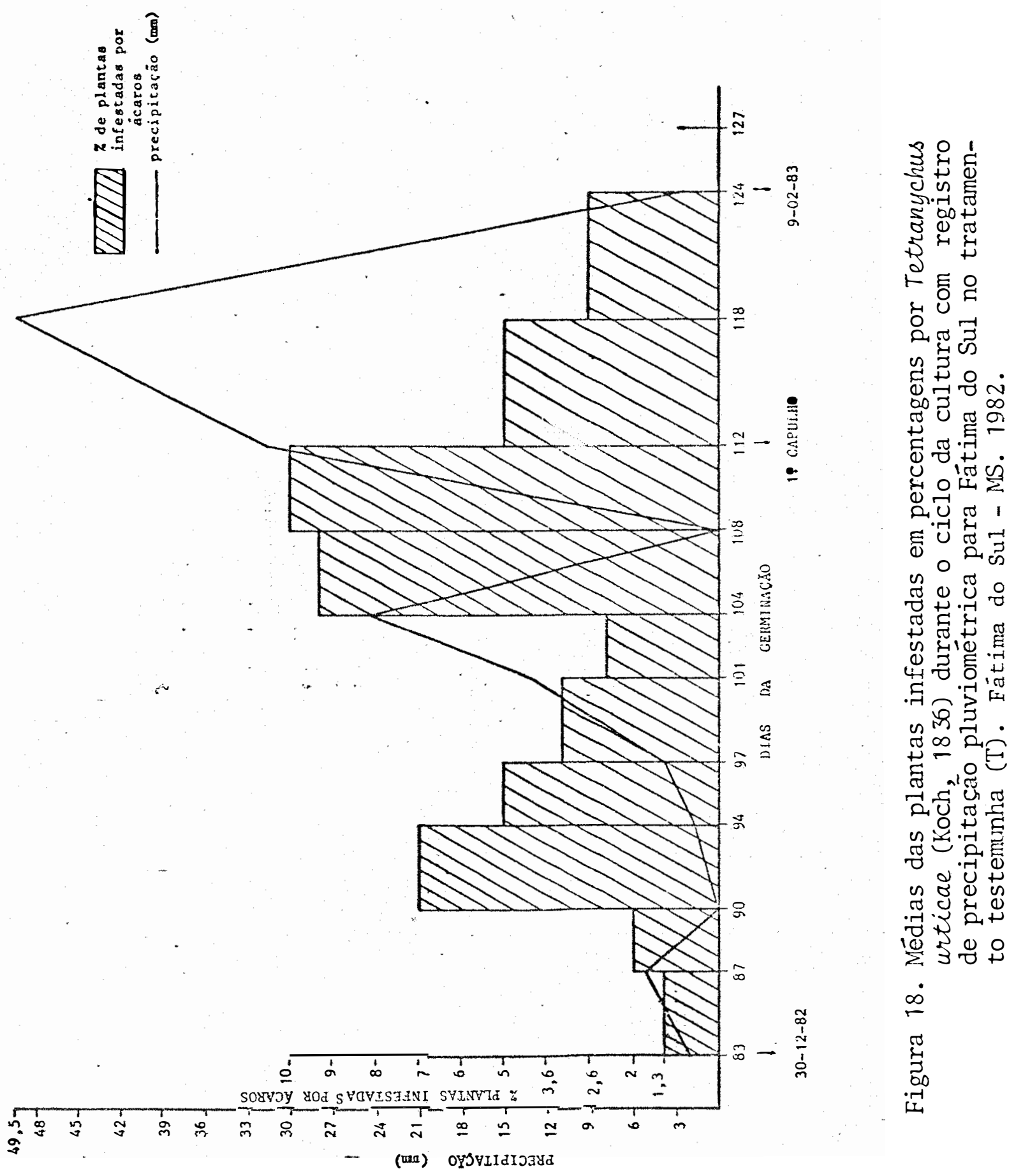




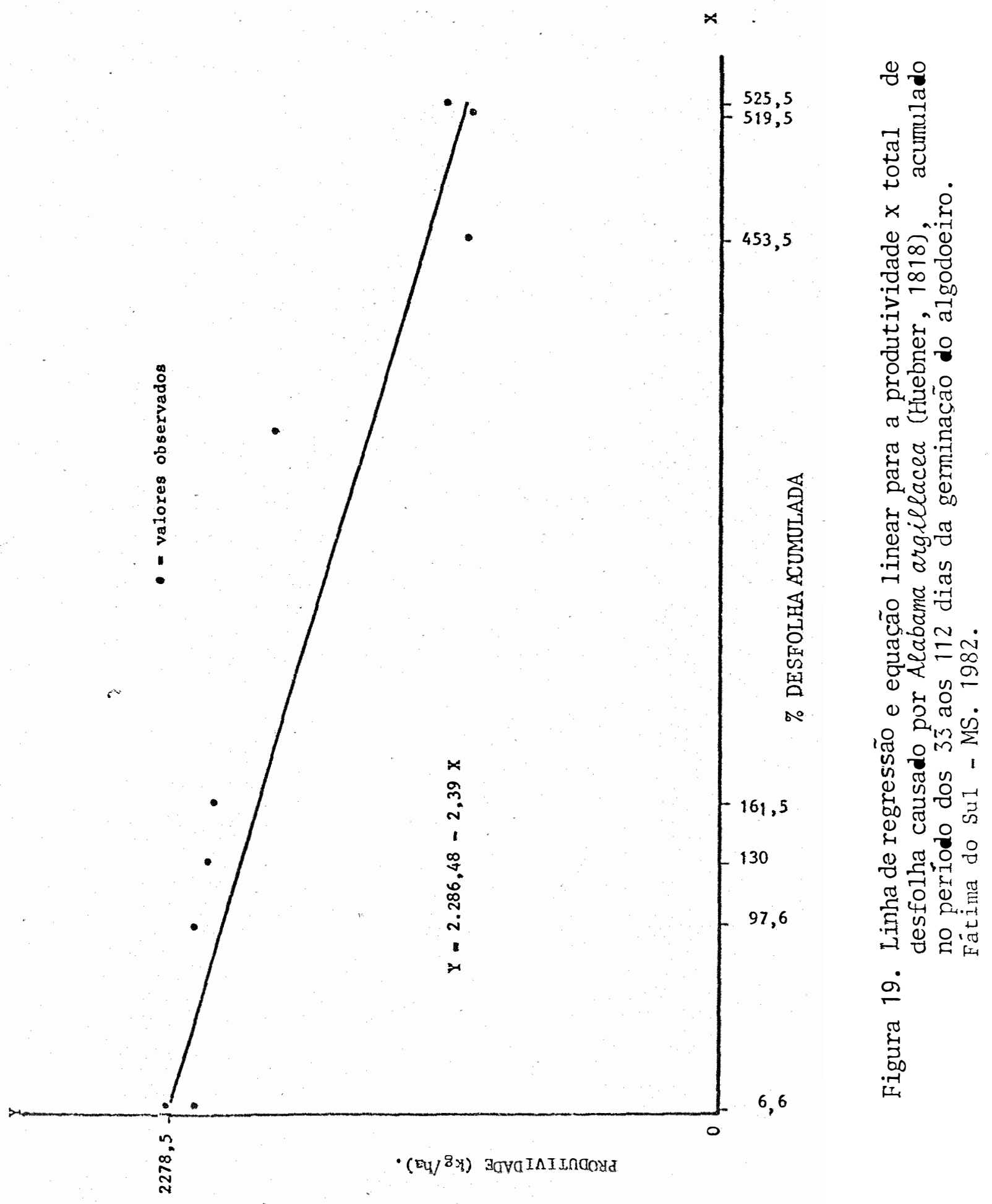




\section{CONCLUUSÕES}

De acordo com os resultados obtidos conclui-se que :

a) Os niveis de controle observados e ajustados para as pragas da região em estudo não causam redução na produtividade do algodoeiro.

b) O manejo de pragas do algodoeiro proporciona as seguintes vantagens:

1- Diminuição drâstica no nûmero de aplicações de defensivos sem queda na produtividade.

2 - Preservação dos inimigos naturais das pragas do algodoeiro

3- o controle do äcaro rajado em reboleira per 
mite economia de defensivos e preserva os inimigos naturais. 4- 0 uso de sementes tratadas com inseticida sistêmico reduz o custo de controle de tripes, possibilitando ainda o controle simultâneo dos pulgões que surgem tardiamente e do curuquerê com economia de defensivos e preservaçãodos inimigos naturais.

c) Os artrópodos predadores mais abundantes fo ram: coccinelídeos, sirfídeos, crisopideos, Geocoris sp., Reduviídeos, orius sp., e aranhas.

d) A maior infestação de ácaro rajado ocorre durante os períodos de baixa precipitação pluvial.

e) Altas precipitações pluviais reduzem sensivelmente as populações de ácaro rajado.

f) A produtividade do algodão decresce linearmente com o aumento da desfolha das plantas.

g) O manejo de pragas do algodoeiro mostra-se viâvel têcnica e economicamente, podendo ser adotado pelos co tonicultores da região. 


\section{LITERATURA CITADA}

ADKISSON, P.L., 1972. The integrated control of the insect pests of cotton. In : Proceedings Annual Tall Timbers conference on Ecological Animal Control by Habitat Management. Texas, College Station, p. 175-178.

ARAUJO, C.A.M., 1981. Estratëgias de manejo integrado de Heliothis spp e Alabama argillacea, (Huebner, 1818) (LEPIDOPTERA, NOCTUIDAE) em algodoeiro na região de Jaboticabal, SP. JABOTICABAL, Faculdade de Ciências Agrärias e Veterinárias/UNESP, 81p. (Trabalho para graduação em Agronomia)

BEINGOLEA, G.0., 1980. El futuro del control integrado de las plagas agricolas. Revista Peruana de Entomologia. Lima 23 (1):7-15 
BISHOP, A.L. e P.R.B. BLOOD, 1977. A record of beneficial arthropods and insect diseases in southeast Queensland Cotton. Pans. London, $23: 384-386$

BLEICHER, E. e C.T. FERRAZ, 1980. Sugestões para o controle. das pragas do algodoeiro no Estado de Mato Grosso do Sul. Campina Grande, EMBRRAPA-CNPA, 16p. (Comunicado Técnico)

BLEICHER, E. e F.M.M. de JESUS, 1982. Uso de inseticidas seletivos no controle do curuquerê do algodoeiro, Al:hama argillacea, (Huebner, 1818). In : II Reunião Nacional do Algodão. Salvador, EMPRAPA-CNPA. Resumos, p. 172 .

BLEICHER, E.; C.T. FERRAZ e F.M. LAMAS, 1985. Sugestões para o controle de pragas do algodoeiro no estado de Mato Grosso do Sul. Campo Grande, EMPAER 15p. (Comunicado Tëcnico).

BOTTRELL, D.G. e P.L. ADKISSON, 1977. Cotton insect pest management. Ann, Rev. Entomol. Texas, 22 : 451-481

CHIAVEGATO, I.G., 1971. Contribuição ao estudo dos ácaros da cultura algodoeira em algumas regiões do Estado de São Paulo. Piracicaba, ESALQ/USP, 135p. (Tese de Doutoramento) 
CRUZ, V.R., 1982. Evolução do controle de pragas na região algodoeira de Santa Cruz das Palmeiras (SP). In : Reunião Nacional do Algodão. Salvador, EMBRAPA-CNPA. Resumos, p.209.

DEBACH, P., 1974. Biological control by natural enemies. Riverside, Cambridge University Press. 323 p.

EHLER, L.E., 1977. Natural enemies of cabbage looper on cotton in São Joaquim Valley. Hilgardia. Berkeley, 45 (3): $73-106$.

ELIAS, L.A. e A. ORTEGA, 1965. Evaluacion de los programas de aplicaciones de inseticidas contra las plagas del algodonero em el Valle del Yaqui, Sonora. Agricultura Tecnica. Mexico $\underline{2}(5): 232-236$

BRASIL. EMPRESA BRASILEIRA DE PESQUISA AGROPECUARIA. CENTRO NACIONAL DE PESQUISA DE ALGODAO, 1980, Relatồrio Tếcnico Anual - 1977-78. Campina Grande, 194p.

FALCON, L.A., 1971. Progresso del control integrado en el algodon de Nicaragua. Revista Peruana de Entomologia. Lima $14(2): 376-378$.

FALCON, L.A. e R.F.: SMITH, 1974. Manual de =ontrol integrado de plagas del algodonero. Doma, ONU/FAO, 87p. 
FERRAZ, C.T. e E. BLEICHEP, 1982. Manejo integrado de pragas do algodoeiro em Mato Grosso do Sul. In : II Reunião Nacional do Algodão. Salvador, EMBRAPA-CNPA. Resumos, p.178

FERREIRA, L., 1980. Manejo integrado de pragas do algodoeiro em Minas Gerais. In : I Reunião Nacional do Algodão. Londrina, EMBRAPA/CNPA. Resumos, p. 100

FURR, R.E. e T.R. PFRIMMER, 1968. Effects of earlymid, and late-season infestations of two-spotted spider mites on the yield of cotton. J. Econ. Entomol. Menasha 61 (5) : 1446-1447.

GEIER, P.W. e R.L. CLARK, 1961. An ecological approach to pest control. In : Proceedings of the Eighth Tecnical Meeting, International Ünion for Conservation of Nature an Natural Resources. Warsaw, p.10-18.

GEIER, P.W., 1970. Organizing large-scale projects in pest management. In : Meeting on cotton Pests, Panel of Experts on Control. Roma, FAO, 8p.

GONZALES, R.H., 1977. Combate de las plagas en la America Latina. Revista Agricultura de las Americas. Roma, $\underline{26}$ (12) : $18-63$ 
GILES, J.A.; E.C. FREIRE e E. BLEICHER, 1979. Relatório da Comissão do CNP-Algodão encarregada de levantar a problemática do cultivo do algodão no Estado de Mato Grosso do Sul. Campina Grande, EMBRAPA-CNPA, $11 \mathrm{p}$.

GRAVENA, S.; E. MATRANGOLO Jr. e J.A. PAZETto, 1985.

Seletividade de Chlorpyrifós utilizado no controle de Aphis gossypii. Glover a artrópodos benéficos na cultura algodoeira. Ecossistema. Espírito Santo do Pinhal 10 : $113-118$.

HEADLEY, J.C., 1973. Environment quality and the economics of agricultural pest control. Eppo Bul1. 3 (3) : 51-61

HUFFAKER, C.B., 1975. Biological control in the management of pests. Agro-Ecosystems. Amsterdã, $\underline{2}$ : 15-31

JESUS, F.M.M. de; E. BLEICHER; J.R. CRISÓSTONO e E.F. LIMA, 1984 Manejo integrado das pragas do algodoeiro no Brasil, situação e perspectivas. Campina Grande, EMBRAPA-CNPA, $21 \mathrm{p}$.

JIN, T. e A.L. da SILVA, 1978. Diagnóstico da cultura algodoeira no Estado de Goiás. Goiânia, ENGOPA, 12p. (Comunicado Técnico) 
KOGAN, M. 1980. Criação de insetos: bases nutricionais e aplicações em programas de manejo de pragas. In : Anais do VI Congressd Brasileiro de Entomologia. Campinas Fundação Cargill, p.45-75.

LUCKMANN, W.H. e R.L. NETCALF, 1975, The Pest-Management Concept. In : METCALF, R.L. e W.H. LUCKMANN, Introduction to insect pest management. New York, John Wiley e Sons Eds, p. 3-35.

MARUR, C.J. e W.J. SANTOS, 1980. O desfolhamento simulado e o provocado pelo curuquerê Alabama argillacea (Hueb., 1818) em algodoeiro cultivado no Estado do Paraná. In I Reunião Nacional do Algodão. Londrina, EMBRAPA-CNPA. Resumos, f.104

NAKANO, 0. 1980. Planejamento de controle das pragas do algodoeiro em São Paulo. Revista Agropecuāria. São Paulo $21: 27-33$

NAKANO, O., S. SILVEIRA NETO e R.A, ZUCCHI, 1981. Entomologia Econômica. São Paulo, Livroceres 314 p.

NAKANO, O. e C.A. PEREZ, 1981. La decamethrine en culture cotonniere du Brésil. In : International Conference on Tropical Crop Protection 
NAKAYAMA, K.; L.C. BONELLI; C.G. GREEN; F.ORSI JUNIOR, 1982. Avaliação do manejo de pragas do algodoeiro no Mato Grosso do Sul. In : II Reunião Nacional do Algodão. Salvador EMBRAPA-CNPA. Resumos. p.207

NICKEL, J.L., 1960. Temperature and humidity relation ships to Tetranychus desertorum Banks with special reference to distribution. Hilgardia, Berkeley, 30(2) . 41-1.00.

OLIVETRA, C.A.L. de e A.P. VERCESI, 1983. Efeito de piretróides sobre a população de ácaro rajado Tetranychus urticae Koch,18 3ó na cultura do algodoeiro. Ecossistema. Espírito Santo do Pinhal, $\underline{8}: 101-106$

REIS, P.R.,1972. Efeito do äcaro Tetranychus urticae Koch, 1836 (Acarina:Tetranychidae) na produção e qualidade da fibra do algodoeiro, variedade IAC-RM ${ }_{2}$. Piracicaba, ESALQ/USP, 76p. (Tese de Doutoramento)

RENOU, A. e R. DELATTRE, 1981. Action de Certains inseticides sur le poids moyen capsulaire chex le cotonnier. In : International Conference on Tropical Crop Protection. Lyon p. 81

ROUSH, R.T. e D.A. WOLFETBARGER, 1985, Inheritance of Methomyl Resistance in the Tobacco Budwarm (Lepidoptera:Noctuidae). J.Econ. Entomol. Mienasha, 78 (5): 1020-1022 
SANTOS, W.J., 1980. Manejo de pragas do algodoeiro. Londrina EMATER-PR/ACARPA. $31 \mathrm{p}$.

SANTOS, W. J., 1980. Ccorrência dos pulgões, Aphis gossypii

- Glover, 1877 , e seus efeitos na produção do algodoeiro cultivado no Estado do Paraná. In : I Reunião Nacional do Algodão. Londrina, EMBRAPA-CNPA. Resumos, p.105.

SANTOS, W.J., 1982. Ocorrência de tripes Frankliniella sp. e seus efeitos no desenvolvimento e produção do algodceiro. In : II Reunião Nacional do Algodão. Salvador, EMBRAPA-CNPA Resumos, p.204.

SANTOS, W.J., 1984. Ocorrência e danos da lagarta rosada, Pectinophora gossypiella Saund., 1844 em algodoeiro no Estado do Paraná. In : II I Reunião Nacional do Algodão. Recife, EMBRAPA-CNPA. Resumos, p, 154.

SATO, O.; J.D.B. FELIZARDO; E.A. NEEGRÃO e W.S. GOTO, 1984. Efeito dos inseticidas em tratamento de semente no controle de tripes Thrips tabaci Lind, 1838 e Frankliniella sp e pulgão Aphis gossypii Glover, 1876 na cultura do algodoeiro In : III Reunião Nacional do Algodão. Recife, EMBRAPA-CNPA $\underline{\text { Resumos, p. } 155}$ 
SETTEN, M.L.; M.J. FORNAZ IER; O. NAKANO, 1982. Observações sobre oviposição do äcaro rajado Tetranychus urticae Koch, 1856 quando pulverizado com defensivos químicos em folhas do algodoeiro. In : II Reunião Nacional do Algodão. Salvador EMBRAPA-CIIPA. Resumos, p.231.

SILVA. A.L. da; P.C.N. do PRADO e H.F. da CUNHA, 1981. Manejo das principais pragas do algodoeiro em Goiās. Goiânia, ENGOPA, 19p. (Circular Técnica)

SMITH, R.F.; J.L. APPLER e D.G. BOTTRELL, 1976. The origins of Integrated Pest Nanagement Concepts for Agricultural Crops. In : J.L. APPLi e R.F. SMITH (eds). Integrated Pest Management. New York, Plenum Press, p.1-27

STAETZ, C.A., 1985. Susceptibility of Heliothis virescens (F.) (Lepidoptera: Noctuidae) to Permethrin fron Across the Cotton Belt: A Five-year study. J. Econ. Entomol. Menasha, $\underline{78}$ (3) : 505-510.

SUEKANE, O.H. e G.N. WASSANO, 1982. Flutuação populacional de inimigos naturais e pragas principais em algodão em Naviraí, NS. In : II Reunião Nacionaj do Algodão. Salvador EMBRAPA-CNPA. Resumios, p.189.

SUNA AGRICOLA E PECUẢRIA, 1985. Ed. Tana Itda, Rio de Janeiro (23): $1-8$. 
VENDRAMIM, J.D., 1984. A resistência de plantas e o manejo de pragas. In : CROCOMO, W. B., Ed. Manejo de Pragas. Botucatu, FEPAF, p. 117-144 
.85.

\section{APẼMDICE}


Apēndice 1. Dados meteorológicos diärios do mēs de outubro de 1982. FATIMA DO SUL - MS.

\begin{tabular}{|c|c|c|c|c|c|}
\hline Dias & $T M$ & Tn & $\mathbf{T}$ & UR & P \\
\hline 1 & 33.6 & 16,7 & 22,4 & 70 & 0,0 \\
\hline 2 & 22,1 & $18, ?$ & 19,2 & 92 & $2 i, 2$ \\
\hline 3 & 28,0 & 16,6 & 21,6 & 88 & $\epsilon, 1$ \\
\hline 4 & 32,9 & 19,2 & 25,9 & 70 & 0,0 \\
\hline 5 & 28,5 & $2 \pi, 1$ & 22,8 & 91 & 0,0 \\
\hline 6 & 25,7 & 16,6 & 21,4 & 90 & 12,2 \\
\hline 7 & 30,2 & 20,1 & 24,5 & 78 & 0,2 \\
\hline 8 & 25,8 & 19,4 & 21,0 & 92 & 39,4 \\
\hline 9 & 27,7 & 18,5 & 22,3 & 90 & 97,7 \\
\hline 10 & 25,3 & 20,3 & 21,5 & 90 & 9,7 \\
\hline 11 & 26,5 & 18,3 & 22,2 & 83 & 4,6 \\
\hline 12 & 32,9 & 19,6 & 26,1 & 67 & 0,0 \\
\hline 13 & 26,6 & 13,9 & 17,2 & 56 & 30,6 \\
\hline 14 & 24,0 & 8,2 & 17,0 & 65 & 0,0 \\
\hline 15 & 29,6 & 14,2 & 22,2 & 59 & 0,0 \\
\hline 16 & 30,6 & 18,4 & 24,5 & 60 & 0,0 \\
\hline 17 & 35,5 & 19,9 & 27,3 & .62 & 0,0 \\
\hline 18 & 28,0 & 12,7 & 18,3 & 21 & 41,2 \\
\hline 19 & 27,2 & 12,4 & 20,6 & 34 & 0,0 \\
\hline 20 & 33,2 & 19,4 & 26,1 & 67 & 0,0 \\
\hline 21 & 34,7 & 20,6 & $2 i, 1$ & 63 & 0,0 \\
\hline 22 & 34,9 & 21,7 & 27,7 & 61 & 0,0 \\
\hline 23 & 33,4 & 23,0 & 27,7 & 70 & 0,0 \\
\hline 24 & 27,3 & 20,6 & 22,7 & 92 & 2,3 \\
\hline 25 & 32,3 & 20,2 & 24,7 & 88 & 4,7 \\
\hline 26 & 31,3 & 20,7 & 26,0 & 76 & 0,9 \\
\hline 27 & 32,9 & 21,9 & 25,9 & 75 & 0,0 \\
\hline 28 & 32,2 & 20,2 & 25,9 & 72 & 0,0 \\
\hline 29 & 33,6 & 20,3 & 26,8 & 63 & 0,0 \\
\hline 30 & 31,5 & 21,6 & 25,0 & 59 & 4,8 \\
\hline 31 & 31,7 & 13,6 & 23,3 & 48 & 0,1 \\
\hline Total média & 30,0 & 18,3 & 23,4 & 74 & 275,7 \\
\hline
\end{tabular}


Apêndice 2. Dados meteorológicos diärios do més de novembro de 1982. FATIMA DO SUL - MS.

\begin{tabular}{|c|c|c|c|c|c|}
\hline Dias & $\mathrm{TM}$ & In & $T$ & UR & $P$ \\
\hline 1 & 34,5 & 18,6 & 27,0 & 56 & 0,0 \\
\hline .2 & 34,0 & 23,0 & 28,0 & 59 & 0,0 \\
\hline 3 & 32,6 & 20,6 & 26,1 & 80 & 0,0 \\
\hline 4 & 29,5 & 21,0 & 24,4 & 92 & 5,1 \\
\hline 5 & 28,7 & 20,7 & 23,3 & 91 & 32,1 \\
\hline 6 & 23,4 & 17,2 & 20,2 & 96 & 35,3 \\
\hline 7 & 29,6 & 19,6 & 23,5 & 83 & 1,4 \\
\hline 8 & 31,2 & 19,6 & 24,8 & 84 & 0,0 \\
\hline 9 & 33,0 . & 19,8 & 26,1 & 74 & 0,1 \\
\hline i & 32,7 & 22,2 & 26,0 & 78 & 1,3 \\
\hline 11 & 32,4 & 18,5 & 22,9 & 88 & 6,2 \\
\hline 12 & 27,7 & 18,2 & 22,1 & 91 & 9,7 \\
\hline 13 & 32,0 & 20,0 & 26,0 & 74 & 18,5 \\
\hline 14 & 26,5 & 20,0 & 23,8 & 95 & 4,0 \\
\hline 15 & 26,2 & 21,4 & 23,1 & 96 & 20,8 \\
\hline 16 & 28,6 & 21,4 & 24,4 & 92 & 3,0 \\
\hline 17 & 30,0 & 21,4 & 24,9 & 91 & 2,5 \\
\hline 18 & 32,6 & 21,8 & 27,5 & $8 i$ & 0,0 \\
\hline 19 & 32,5 & 21,8 & 24,9 & 87 & 0,0 \\
\hline 20 & 31,1 & 21,1 & 25,4 & 79 & 8,0 \\
\hline 21 & 24,7 & 19,6 & 21,9 & 98 & 13,5 \\
\hline 22 & 28,0 & 20,1 & 24,3 & 90 & 30,2 \\
\hline 23 & 29,0 & 21,3 & 23,2 & 97 & 12,3 \\
\hline 24 & 30,9 & 19,8 & 24,7 & 90 & 22,0 \\
\hline 25 & 33,0 & 21,5 & 27,0 & 84 & 0,0 \\
\hline 26 & 33,1 & 22,6 & 25,6 & 79 & $\quad 0,2$ \\
\hline 27 & 34,2 & 20,7 & 27,0 & 74. & 0,5 \\
\hline 28 & 33,8 & 21,6 & 26,5 & 72 & 0,0 \\
\hline 29 & 33,6 & 19,4 & 24,5 & 84 & 0,0 \\
\hline 30 & 34,7 & 20,3 & 25,4 & 78 & 1,0 \\
\hline Total média & 30,8 & 20,5 & $24 ; 9$ & 83 & 227,7 \\
\hline
\end{tabular}

$T M=$ tempertatura média das máximas absolutas - ${ }_{0}^{\mathrm{C}}$

To = temperatura média das mínimas absolutas $-{ }^{0} \mathrm{C}$

$\mathbf{T}$ = temperatura média-oC

UR = umidace relativa -2

$P=$ recipitação - m 
Apéndice 3. Dados meteorológicos diärios do mēs de dezembro de 1982. FÁTIMA DO SUL - MS.

\begin{tabular}{|c|c|c|c|c|c|}
\hline Dias & $T M$ & Tom & $\mathbf{T}$ & UR & $\mathbf{P}$ \\
\hline 1 & 33,7 & 20,4 & 25,7 & 75 & $3, \dot{4}$ \\
\hline 2 & 32,3 & 20,6 & 24,1 & 94 & 0,0 \\
\hline 3 & 29,2 & 18,0 & 23,4 & 75 & 0,0 \\
\hline 4 & 28,4 & 18,0 & 22,7 & 68 & 0,0 \\
\hline 5 & 31,6 & 17,7 & 24,5 & 71 & 0,0 \\
\hline 6 & 25,8 & 19,4 & 21,0 & 96 & 12,6 \\
\hline 7 & 27,7 & 18,6 & 21,9 & 74 & 11,7 \\
\hline 8 & 29,2 & 12,9 & 21,1 & 57 & 0,0 \\
\hline 4 & 30,7 & 14,4 & 23,4 & 58 & 0,0 \\
\hline 10 & 31,6 & 18,2 & 25,1 & 66 & 0,0 \\
\hline 11 & 31,6 & 20,9 & 23,8 & 83 & 0,0 \\
\hline 12 & 28,2 & 18,8 & 22,7 & 92 & 37,7 \\
\hline 13 & 23,3 & 19,7 & 21,4 & 97 & 13,8 \\
\hline 14 & 25,8 & 20,7 & 22,4 & 93 & 31,1 \\
\hline 15 & 29,1 & 19,3 & 24,1 & 87 & 0,0 \\
\hline 16 & 30,6 & 21,6 & 23,9 & 88 & 0,0 \\
\hline 17 & 25,1 & 20,1 & 21,8 & $98^{-}$ & 20,2 \\
\hline 18 & 28,1 & 20,2 & 23,2 & 90 & 25,4 \\
\hline 19 & 26,9 & 20,3 & 22,7 & 89 & 13,7 \\
\hline 20 & 30,2 & 18,8 & 24,7 & 83 & 0,0 \\
\hline 21 & 31,6 & 21,8 & 26,2 & 80 & 10,7 \\
\hline 22 & 25,7 & 20,0 & 22,2 & 96 & 29,9 \\
\hline 23 & 28,6 & 19,7 & 22,5 & 83 & 30,6 \\
\hline 24 & 29,0 & 17,5 & 23,3 & 72 & 0,0 \\
\hline 25 & 30,2 & 16,7 & 24,1 & 71 & 0,0 \\
\hline 26 & 30,5 & 16,6 & 24,3 & 66 & 0,0 \\
\hline 27 & 32,1 & 16,7 & 25,1 & 66 & 0,0 \\
\hline 28 & 27,7 & 19,7 & 23,1 & 85 & 0,0 \\
\hline 29 & 28,7 & 19,0 & 23,6 & 85 & 0,0 \\
\hline 30 & 30,7 & 19,8 & 23,8 & 83 & 0,0 \\
\hline 31 & 29,9 & $18 ; 8$ & 24,7 & 90 & 0,0 \\
\hline Total nédia & 29,1 & 18,9 & 23,4 & 81. & 240,8 \\
\hline
\end{tabular}


Apêndice 4. Dados meteorológicos diärios do mês de janeiro de 1383. FATIMA DO SUL - MS.

\begin{tabular}{|c|c|c|c|c|c|}
\hline Dias & $M$ & $\operatorname{Tm}$ & $T$ & UR & $P$ \\
\hline 1 & 31,8 & 22,2 & 25,4 & 75 & 5,1 \\
\hline 2 & 31,8 & 19,9 & 25,8 & 75 & 0,1 \\
\hline 3 & 32,8 & 20,5 & 25,6 & 78 & 0,0 \\
\hline 4 & 31,0 & 20,5 & 24,8 & 86 & 0,0 \\
\hline 5 & 31,2 & 20,1 & 25,3 & 80 & 0,0 \\
\hline 6 & 34,0 & 19,2 & 26,1 & 21 & 0,0 \\
\hline 7 & 32,9 & 21,8 & 26,7 & 78 & 0,0 \\
\hline 8 & 32,6 & 22,3 & 25,9 & 79 & 0,2 \\
\hline 9 & 33,5 & 20,3 & 25,0 & 75 & 0,0 \\
\hline 10. & 30,0 & 21,4 & 25,2 & 90 & 1,1 \\
\hline 11 & 31,5 & 22,1 & 25,6 & 86 & 2,5 \\
\hline 12 & 33,0 & 22,4 & 26,1 & 85 & 1,2 \\
\hline 13 & 33,3 & 22,7 & 25,8 & 83 & 0,0 \\
\hline 14 & 29,1 & 23,1 & 24.7 & 89 & 2,2 \\
\hline 15 & 31,7 & 21,7 & 25,3 & 89 & 2,2 \\
\hline 16 & 30,8 & 21,6 & 24,9 & $=87$ & 8,6 \\
\hline 17 & 31,4 & 22,7 & 26,2 & 80 & 0,1 \\
\hline 88 & 31,7 & 22,6 & 25,3 & 86 & 0,3 \\
\hline 19 & 29,4 & 21,6 & $-23,9$ & 89 & 17.3 \\
\hline 20 & 31,4 & 21,0 & 25,2 & 83 & 6,6 \\
\hline 21 & 33,0 & 21,3 & 26.7 & 72 & 0,0 \\
\hline 22 & 34,7 & 20,9 & 27,2 & 73 & 0,0 \\
\hline 23 & 33,6 & 19,0 & 26,7 & 29 & 0,0 \\
\hline 24 & 32,0 & 21,0 & 24,1 & 78 & 0,0 \\
\hline 25 & 31,0 & 20,1 & 24,9 & 79 & 5,3 \\
\hline 26 & 32,4 & 21,7 & 25,1 & 83. & 0,0 \\
\hline 27 & 30,6 & 20,2 & 25,1 & 88 & 26,6 \\
\hline 28 & 29,1 & 23,5 & 25,0 & 96 & 0,0 \\
\hline 29. & 30,2 & 22,3 & 25,2 & 84 & 15,1 \\
\hline 30 & 31,6 & 22,9 & 25,4 & 82 & 0,3 \\
\hline 31 & 28,4 & 21,3 & 23,5 & 90. & $34, i$ \\
\hline Total & 31,7 & 21,4 & 25,4 & 82 & 128,9 \\
\hline
\end{tabular}

TM = temperatura media das máximas absolutas - ${ }^{\circ} \mathrm{C}$

Tn = temperatura média das minimas absolutas - ${ }^{\circ} \mathrm{C}$

$T=$ temperatura média-OC

$U R=$ umiciade relativa .. $\%$

$P$ - precipitação - rm 
Apêndice5. Dados meteorológicos diärios do més de fevereiro de 1983. FATIMA DO SUL - MS.

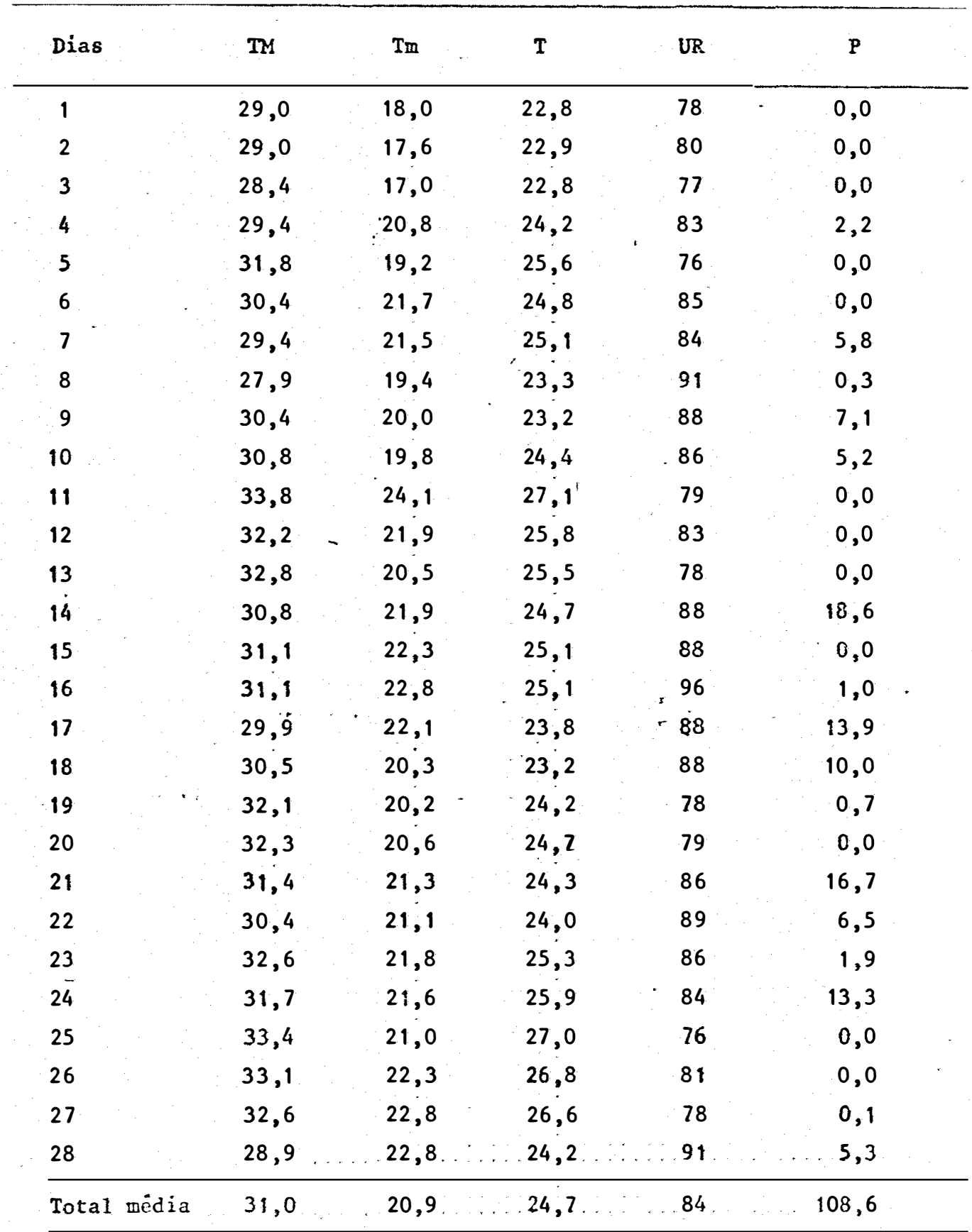

$T M=$ temperatura média das mäxinas absolutas - ${ }^{\circ} \mathrm{C}$

$\mathrm{Tm}=$ temperatura média das minimas absolutas $-{ }^{\circ} \mathrm{C}$

$T=$ temperatura média-oC

UR = umidade relativa - \%

$P=$ precipitaçäo - m 